\title{
Monkey Bars and Ladders: The Importance of Lateral and Vertical Movements in Internal Labor Market Careers
}

Citation for published version (APA):

Dohmen, T. J., Kriechel, B., \& Pfann, G. A. (2004). Monkey Bars and Ladders: The Importance of Lateral and Vertical Movements in Internal Labor Market Careers. Journal of Population Economics, 17(2), 193228. https://doi.org/10.1007/s00148-004-0191-4

Document status and date:

Published: 01/01/2004

DOI:

10.1007/s00148-004-0191-4

Document Version:

Publisher's PDF, also known as Version of record

Please check the document version of this publication:

- A submitted manuscript is the version of the article upon submission and before peer-review. There can be important differences between the submitted version and the official published version of record.

People interested in the research are advised to contact the author for the final version of the publication, or visit the DOI to the publisher's website.

- The final author version and the galley proof are versions of the publication after peer review.

- The final published version features the final layout of the paper including the volume, issue and page numbers.

Link to publication

\footnotetext{
General rights rights.

- You may freely distribute the URL identifying the publication in the public portal. please follow below link for the End User Agreement:

www.umlib.nl/taverne-license

Take down policy

If you believe that this document breaches copyright please contact us at:

repository@maastrichtuniversity.nl

providing details and we will investigate your claim.
}

Copyright and moral rights for the publications made accessible in the public portal are retained by the authors and/or other copyright owners and it is a condition of accessing publications that users recognise and abide by the legal requirements associated with these

- Users may download and print one copy of any publication from the public portal for the purpose of private study or research.

- You may not further distribute the material or use it for any profit-making activity or commercial gain

If the publication is distributed under the terms of Article 25fa of the Dutch Copyright Act, indicated by the "Taverne" license above, 


\title{
Monkey bars and ladders: The importance of lateral and vertical job mobility in internal labor market careers
}

\author{
Thomas J. Dohmen ${ }^{1}$, Ben Kriechel ${ }^{2}$, Gerard A. Pfann ${ }^{3}$ \\ ${ }^{1}$ IZA, P.O. Box 7240, 53072 Bonn, Germany \\ (Fax: + 49-228-3894-510; e-mail: dohmen@iza.org) \\ ${ }^{2}$ Maastricht University, ROA, P.O. Box 616, 6200 MD Maastricht, The Netherlands \\ (Fax: +31-43-388-4914; e-mail: ben.kriechel@roa.unimaas.nl) and IZA \\ ${ }^{3}$ Maastricht University, BIRC, P.O. Box 616, 6200 MD Maastricht, The Netherlands \\ (Fax: + 31-43-388-4856; e-mail: g.pfann@ke.unimaas.nl) and IZA and C.E.P.R
}

Received: 2 September 2002/Accepted 12 August 2003

\begin{abstract}
This paper compares results from the empirical literature on internal labor markets with outcomes from analyzing personnel data of the Dutch aircraft manufacturer Fokker. It sheds light on differences in the functioning of internal labor markets between periods of workforce growth and decline. Despite substantial variation in individual wages, careers are important as wages are strongly related to job levels. Promotion rates fall and demotion rates rise when the firm enters the stage of demise. Vertical and lateral job mobility are important in internal labor market careers as they stimulate wage growth and reduce the lay-off risk.
\end{abstract}

JEL classification: M51, J31, J41

Key words: Internal labor markets, human resource management, personnel economics

\footnotetext{
All correspondence to Thomas Dohmen. This work has benefited from comments and suggestions on earlier drafts by Mike Gibbs, Derek Neal, Niels Westergård-Nielsen, and three anonymous referees. We are grateful for contributions from seminar participants at the universities in Aarhus, Maastricht, and Chicago, and at IZA in Bonn, as well as from participants at the 6th Spring Meeting of Young Economists in Copenhagen, the 2001 Annual Meeting of the European Economic Association in Lausanne, CAED 2001 in Aarhus, and the 2002 CEPR conference 'Incentives and Beyond' in Stockholm. The authors like to thank Fokker's bankruptcy trustees, especially Mr. Ben Knüppe, for making the personnel data available, and Mr. Louis Deterink for sharing with us his profound knowledge and insights on corporate through-starts. Gerard Pfann thanks the N.W.O. PIONIER program for financial support. All errors are our own. Responsible editor: Klaus F. Zimmermann.
} 


\section{Introduction}

An important impulse for the development of an "internal labor market" (ILM) literature within the labor economics literature was Doeringer and Piore's (1971) seminal work. They emphasized the institutional character of employment relationships arguing that administrative rules and procedures, i.e. personnel policies, govern employment relationships, which result in outcomes concerning the pricing and allocation of labor that contrast sharply with the predictions of traditional labor economics. Part of this ILM literature has been devoted to study the design and effects of such personnel policies (e.g., Prendergast 1993; Prendergast and Topel 1996; Milgrom and Roberts 1988), while a substantial body of the theoretical literature focuses on job ladders, career movements, promotions, and their relationship to compensation (e.g., Lazear and Rosen 1981; Rosen 1986; Waldman 1984; Gibbons and Waldman 1999a; Gibbons and Waldman 2003). ${ }^{1}$

Although the empirical literature that studies firm personnel records is growing, there is still too little empirical evidence derived from personnel data that record job positions and compensation in firms on which theories of the internal workings of firms can build. Early exceptions include Osterman (1979), Medoff and Abraham (1980), and Lazear (1992). The most detailed empirical study of wage and career dynamics in internal labor markets so far is Baker et al. (1994a, 1994b) (hereinafter, BGH) who analyze a yearly panel of personnel data of management employees from a large U.S. company, which expands over the observation period. Many of their findings - including that career paths are important for the allocation of workers to jobs, that there is a substantial amount of wage variation within job levels in spite of the strong relation between hierarchical levels and compensation, and that there is no evidence of distinct ports of entry and exit as predicted by Doeringer and Piore (1971) - are confirmed by more recent studies (e.g., Ariga et al. 1999; Seltzer and Merrett 2000; Lima 2000; Gibbs and Hendricks 2001; Treble et al. 2001).

We complement this literature by analyzing ten years of personnel records from the Dutch aircraft manufacturer Fokker to assess whether these empirical "facts" are valid for a different firm, in a different industry, over a different period, and in a different economy. While doing so, we provide answers to a number of questions that were advocated by Gibbons (1997) to facilitate the composition of a broader picture of internal labor markets for which individual studies provide pieces of a puzzle based on firm-level data that are often collected in different ways and measure different variables.

We shed light on issues that have not been addressed in this literature so far: Our data set is unique in the empirical literature as it covers an episode of corporate growth as well as an episode of corporate decline. This enables us to explore how personnel decisions of the firm differ between periods of growth and decline. We investigate the consequences of a changing corporate environment for promotion dynamics and organizational stability. We can distinguish between production workers and managers, so that we can examine whether the internal workings of the firm differ with respect to worker type. In addition, we can study whether such differences exist across different fields of activity within the firm, as for instance Production, R\&D, 
Sales \& Customer Relations, or Administration. Finally, in contrast to existing studies, which commonly rely on year-end panel data, we analyze event history data which record the exact timing of all events related to wage or position changes. The knowledge of the exact timing of all events not only allows us to explore whether wage and position changes occur simultaneously, but it allows us also to look at all events that happen, including those that would remain hidden between two cross sections of personnel records. Information that would be lost in yearly cross sections turns out to be substantial, in particular with respect to temporary worker re-allocation and downward mobility.

Our main findings are as follows. A major result of our analysis, which has not received attention in the empirical literature on internal labor markets, concerns the relation between changes in the size of the workforce and internal mobility rates. We find that promotion rates increase during corporate expansion and fall during downsizing, while the reverse is true for demotion rates. The change in job mobility rates is more drastic in the blue-collar ranks, which account for most of the employment variation. ${ }^{2}$ In accordance with the results of BGH, job mobility is substantial in our firm and an important determinant of wages. While upward transition rates are somewhat lower than found for other firms, we do observe a substantial number of lateral transitions. This has not been documented in related studies. Career paths exist that involve lateral job transitions to more attractive jobs. Wriggling the monkey bars of a "flat" within-joblevel-career path is a prevalent route of career development next to climbing the job ladder by upward hierarchical job transitions. Job transitions are the main source for sustained wage growth as wages are strongly related to job levels. Yet we find, like $\mathrm{BGH}$, that wages are not tied to jobs in a strict sense. Considerable wage spread is found in all job levels, and wage distributions of adjacent job levels overlap. In addition, we discover two important novel facts concerning the relation between job transitions and wage changes that are worth mentioning: First, we detect that upward job transitions are not always associated with simultaneous wage raises. Rather, a promotion bonus is frequently awarded some time after the job change. Usually such "late" raises are given at the end of a calendar year for promotions that occurred during the calendar year. Consequently, this effect could not be detected in the previous literature that commonly studied year-end cross section data. Second, although downward mobility almost never results in nominal wage cuts - as is also often reported in the literature cited above - we observe that such a demotion frequently coincides with degradation in wage scales and hence a reduced prospect of future wage growth.

Our paper is organized as follows. Section 2 describes the firm and its personnel data. Section 3 depicts the hierarchical structure of the firm and the procedure used to identify those hierarchical levels. Section 4 analyzes the job mobility pattern. It portrays entry and exit as well as job transitions within the firm. Section 5 examines the relationship between wages and hierarchical job positions. Section 6 takes a closer look at wage growth and its relation to job transitions. Section 7 investigates career paths within the firm and shows that both careers across hierarchies as well as within hierarchical positions exists. Section 8 concludes. 


\section{The firm and its personnel data}

\subsection{The firm}

We have personnel data from the Dutch national aircraft builder N.V. Fokker over the period from January 1, 1987, when the firm introduced its electronic personnel system, until March 15, 1996, when the firm was officially declared bankrupt. ${ }^{3}$ N.V. Koninklijke Nederlandse Vliegtuigenfabriek Fokker was structured in an administration unit (Fokker Administration B.V.), an aircraft production unit (Fokker Aircraft B.V.) with plants in three different locations as well as four other subsidiaries at different locations (see Table A.1 in the Appendix). The majority of the workforce was affected by the bankruptcy of the holding company, the production unit, and the administration unit, which formed the core business of aircraft manufacturing. The other viable parts of the firm did not enter the bankruptcy procedure and were eventually sold. Most of the organizational structure remained unchanged until the day of the bankruptcy, except for one division, Fokker Space, that was spun off in December 1995. ${ }^{4}$

We analyze the data until the bankruptcy date. This might prompt the criticism that the firm is not a representative example of a downsizing firm as it fails eventually. This could be problematic if the demise was expected and if behavior was brought into line with the anticipation of the failure. However, there is reason to believe that the bankruptcy came suddenly and unexpectedly for most of the employees. ${ }^{5}$

\subsection{The data}

We use information on each employee's job, compensation, and demographics. The job position file records every worker's job code, job title, organization code, organization name, the activity his job belongs to, the plant name, as well as the starting and end date of all his job positions within the company during the observation period. The wage files contain information on the salary grade, the nominal wage rate, the start and ending date of the wage contract, the reason for a change in the wage contract, and a performance measure that refers to performance in the previous year. In addition, we know the schooling and the vocational degree of most employees. The file of demographic characteristics has the date of birth, gender, marital status, and the hiring date for every employee. We merged these raw data files into one event history data file. Since we know the exact timing of job changes and wage changes, we can detect whether job changes and wage changes occur simultaneously. Another advantage of our data structure is that we do not lose information about events that happen in the time-span between two cross sections of panel data.

\subsection{Development of the workforce}

The time period spanned by the data can be divided into a period of workforce expansion and one of workforce reduction. The number of employed workers with permanent contracts rises from 10275 in January 
1987 to 12852 at the peak in February 1991. During the subsequent period, which is marked by a series of reorganizations with employment reductions and mass layoffs, the number of employed workers falls to 7141 on the day before the bankruptcy.

Figure 1 plots the number of workers employed at the beginning of each month from January 1987 until March 1996 stacked by ten broad activities into which jobs are categorized. Most workers are employed in one of the five production activities (Assembly (F), Support \& Supplies (G), Production Preparation (D), Planning \& Coordination (E), and Quality (M)). Employment changes in production activities increasing steadily from 6684 workers in January 1987 to a peak of 8838 workers in June 1991, and then falling to 4651 workers on the day before the bankruptcy account for the largest part of the workforce expansion and the subsequent contraction. Employment in the three administrative activities (Finances and Administration (K), Human Resources \& Support $(\mathrm{H})$, and Management \& Information Processing (S)) rises from 1966 workers in January 1987 to 2252 workers in February 1991 and falls subsequently to 1113 workers in March 1996. Employment in R\&D (C) and in Sales \& Customer Relations (B), on the other hand, grows for a prolonged period (peaking not until the second quarter 1993), and declines only moderately until the end of 1995. As a result, the employment share of production related activities falls during the episode of downsizing from a peak of $68.8 \%$ in mid 1991 to $62.3 \%$ in

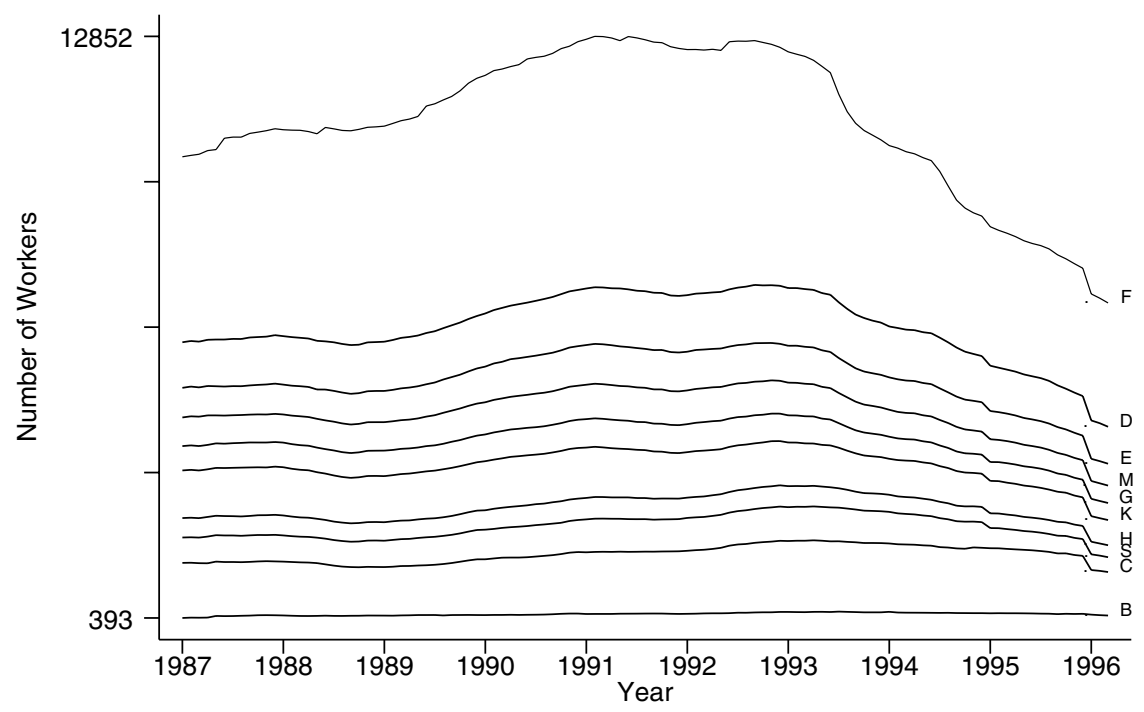

Fig. 1. Development and composition of the workforce by activities. Notes: The figure plots the number of workers with a permanent contract employed at the beginning of each month from January 1987 until March 1996 stacked by the different job activities defined in the data. Job activities comprise: Sales \& Customer Relations (B), R\&D (C), Management \& Information Processing (S), Human Resources \& Support (H), Finances and Administration (K), Support \& Supplies (G), Quality (M), Planning \& Coordination (E), Production Preparation (D), and Assembly (F). Labels are in parentheses. The distance to the next lower line represents the number of workers in a particular job activity. Total employment at the firm is, therefore, characterized by the top line, labelled as " $F$ " 
December 1995 and that of administrative activities falls from $17.1 \%$ in mid 1991 to $15.9 \%$ by the end of 1995 .

\section{The corporate hierarchy}

\subsection{Identification of levels}

We relied on job transitions, job titles, reporting relations and team composition - but we did not use information from the wage files - in order to identify the hierarchical job structure of the firm. There are 6085 different job codes and 6318 different job names in the data. ${ }^{6}$ Fortunately, the number of levels could be inferred easily from transitions between a few important job titles which account for a large portion of the workforce. ${ }^{7}$ We identified 10 hierarchical levels. Production workers, supporting workers (e.g., cleaning, catering, or transportation staff), and lower-level clerical workers are organized in the bottom three levels. We refer to this group of workers as blue-collar workers. Higher level clerical workers form level 4 of the hierarchy. Management and the remaining white-collar workforce are organized in six management levels (levels 5-10). ${ }^{8}$ The 'Executive Board', which consisted of a group of 3 managers most of the time, forms the top of the hierarchy (level 10). Directors of subdivisions and plants are in level 9. For confidentiality reasons, we lack salary information for those employees in levels 9 and $10 .^{9}$ Consequently, analyses involving compensation are only for the bottom 8 levels of the corporate hierarchy. Moreover, due to the small number of employees in the top 3 levels, we group these levels together in our job transition analyses. Level 8 comprises heads of departments. Levels 5, 6, and 7 comprise managers who report to those in level 8 and head or work in lower level departments of the firm. Besides, a large fraction of employees in levels 4 to 6 are engineers or specialists.

Suggestive job titles confirmed the hierarchical structure inferred from job transitions. For example, "Assemblers" or "Lathe Operators" are organized in level 1, whereas team leaders (e.g., a "Team Leader Assembly" or "Team Leader Lathe Operation") are in level 2, and group chiefs (e.g., "Group Chief Assembly" or "Group Chief Lathe Operation") in level 3. Similarly, job titles confirmed our assignment of job codes to higher hierarchical levels. For example, we observe transitions from "Specialist" to "Senior Specialist", or from "Engineer" to "Senior Engineer". These suggestive job titles also facilitated the assignment of minor job codes comprising only one or very few persons, who sometimes had no transition to or from another job code during the observation period. Finally, we exploited information about the composition of teams or subdivisions to assert that the hierarchical structure inferred from job transitions is consistent with the organization of teams in the sense that a team leader is assigned to a higher hierarchical level than the team members reporting to him.

\subsection{Structural stability and the size of levels}

Table 1 reveals the pyramid structure of the hierarchy with "sub-pyramids" for blue-collar and white-collar job levels. We find that many features of this 
Table 1. Hierarchical composition, 1987-1996

\begin{tabular}{lrrrrrrrrrr}
\hline Level & \multicolumn{1}{c}{ Year } \\
\cline { 2 - 10 } & 1987 & 1988 & 1989 & 1990 & 1991 & 1992 & 1993 & 1994 & 1995 & 1996 \\
\hline 1 & 51.3 & 52.9 & 53.7 & 54.1 & 53.0 & 52.3 & 50.4 & 45.2 & 42.3 & 43.9 \\
2 & 16.2 & 15.6 & 15.4 & 14.8 & 14.6 & 14.4 & 14.4 & 15.6 & 15.7 & 16.0 \\
3 & 9.0 & 8.6 & 8.6 & 7.9 & 8.3 & 8.5 & 8.7 & 9.2 & 9.7 & 9.8 \\
4 & 11.1 & 10.9 & 10.6 & 11.4 & 11.9 & 11.8 & 12.6 & 13.4 & 13.4 & 12.9 \\
5 & 6.2 & 6.0 & 5.8 & 5.9 & 6.2 & 6.6 & 7.2 & 8.3 & 9.1 & 8.2 \\
6 & 3.4 & 3.4 & 3.3 & 3.3 & 3.5 & 3.7 & 4.0 & 5.2 & 6.2 & 5.6 \\
7 & 1.3 & 1.2 & 1.2 & 1.3 & 1.2 & 1.4 & 1.4 & 1.5 & 1.9 & 1.7 \\
8 & 1.0 & 1.0 & 1.0 & 1.0 & 1.0 & 1.0 & 1.1 & 1.3 & 1.4 & 1.6 \\
$9-10$ & 0.4 & 0.4 & 0.4 & 0.3 & 0.3 & 0.3 & 0.2 & 0.3 & 0.3 & 0.3 \\
Total & 100.0 & 100.0 & 100.0 & 100.0 & 100.0 & 100.0 & 100.0 & 100.0 & 100.0 & 100.0 \\
\hline
\end{tabular}

Note: The table shows for each year the percentage of employees in each of the 10 hierarchial job levels on March 14. Levels 9 and 10 are combined for confidentiality reasons.

hierarchical job structure are remarkably stable over the entire period. The number of levels in the hierarchy is unchanged and the main job titles in each level in 1987 remain in the respective levels until the bankruptcy. ${ }^{10}$ Corresponding with $\mathrm{BGH}$, who report stable relative sizes of hierarchical levels for an expanding firm, we also find that the relative size of levels is largely unaffected by the workforce expansion from 1987 until 1991 (see Table 1). However, relative level sizes change markedly during the period of employment reduction from 1991 until 1996, when the blue-collar share of total employment (levels 1-3) declines from $75.9 \%$ in 1991 to $67.7 \%$ in 1995.

\section{Mobility}

\subsection{Entry and Exit}

Turnover is comparatively low during the first five years of our observation period so that we can confidently speak of an internal labor market: The average annual exit rate equals 7.1\% from January 1987 until March 1991, whereas $\mathrm{BGH}$ find exit rates of $10 \%$ and more when their firm grows at a similar rate as ours.

We do not find evidence of a completely closed internal labor market. Entry occurs into all levels in all years as Table 2 shows. Yet, entry is concentrated in the bottom levels of blue-collar employment (level 1) and of white-collar employment (level 4) - especially during the episode of corporate expansion when $70.3 \%-76.8 \%$ of all beginners, or $85.5 \%-89.5 \%$ of all newly hired blue-collar workers enter level 1 and when $60.1 \%-71.1 \%$ of all newly hired white-collar workers enter level 4 (see Table 2). Relative entry rates into blue-collar ranks are markedly lower during downsizing and entry measured relative to level size is generally less concentrated in bottom ranks from 1992 onwards, possibly because hiring then takes place to staff vacancies in existing slots that cannot be filled from within rather than to hire into slots that are newly created during expansion.

Hiring and firing takes place at all times. Monthly inflow rates are higher and more erratic (with peaks occurring commonly in May) than outflow rates 
Table 2. Entry into hierarchical levels, 1987-1996

\begin{tabular}{lrrrrrrrrrr}
\hline Level & \multicolumn{1}{l}{ Year } \\
\cline { 2 - 10 } & 1987 & 1988 & 1989 & 1990 & 1991 & 1992 & 1993 & 1994 & 1995 & 1996 \\
\hline & 76.8 & 76.6 & 70.9 & 70.3 & 72.0 & 55.5 & 24.3 & 45.2 & 44.1 & 45.8 \\
1 & 6.1 & 8.5 & 7.8 & 6.9 & 7.1 & 5.8 & 15.9 & 5.5 & 13.6 & 12.5 \\
2 & 2.9 & 2.9 & 3.6 & 5.1 & 4.1 & 7.3 & 11.2 & 11.0 & 5.9 & 8.3 \\
3 & 10.1 & 7.3 & 12.1 & 12.2 & 10.8 & 20.6 & 19.6 & 11.0 & 8.5 & 8.3 \\
4 & 2.4 & 2.6 & 3.7 & 4.2 & 3.8 & 8.2 & 15.9 & 9.6 & 16.1 & 0.0 \\
5 & 0.9 & 1.1 & 0.7 & 0.9 & 0.8 & 1.1 & 5.6 & 6.8 & 6.8 & 16.7 \\
6 & 0.5 & 0.2 & 0.8 & 0.2 & 0.8 & 0.6 & 4.7 & 4.1 & 2.5 & 4.2 \\
7 & 0.3 & 0.6 & 0.3 & 0.1 & 0.4 & 0.8 & 0.9 & 4.1 & 1.7 & 4.2 \\
8 & 0.1 & 0.1 & 0.1 & 0.0 & 0.2 & 0.1 & 1.9 & 2.7 & 0.8 & 0.0 \\
$9-10$ & 100.0 & 100.0 & 100.0 & 100.0 & 100.0 & 100.0 & 100.0 & 100.0 & 100.0 & 100.0 \\
Total & 100.0 &
\end{tabular}

Notes: The tables shows for each year the percentage of new hires that entered into the respective level. Levels 9 and 10 are combined for confidentiality reasons.

during corporate expansion, while the opposite holds for the episode of corporate downsizing (see Fig. 2). During early downsizing, in 1991 and 1992, the workforce reduction is mainly accomplished by a fall in the inflow rate, while the outflow rate rises only slightly. The dramatic decline in employment during 1993-1996, however, is brought about by a substantial increase in the outflow rate and a further drop of the inflow rate. ${ }^{11}$ Remarkable are the enormous jumps in outflow in June 1993, June-August 1994, December 1994, and December 1995, which follow downsizing announcements in April 1993, April 1994, and January 1995 respectively.

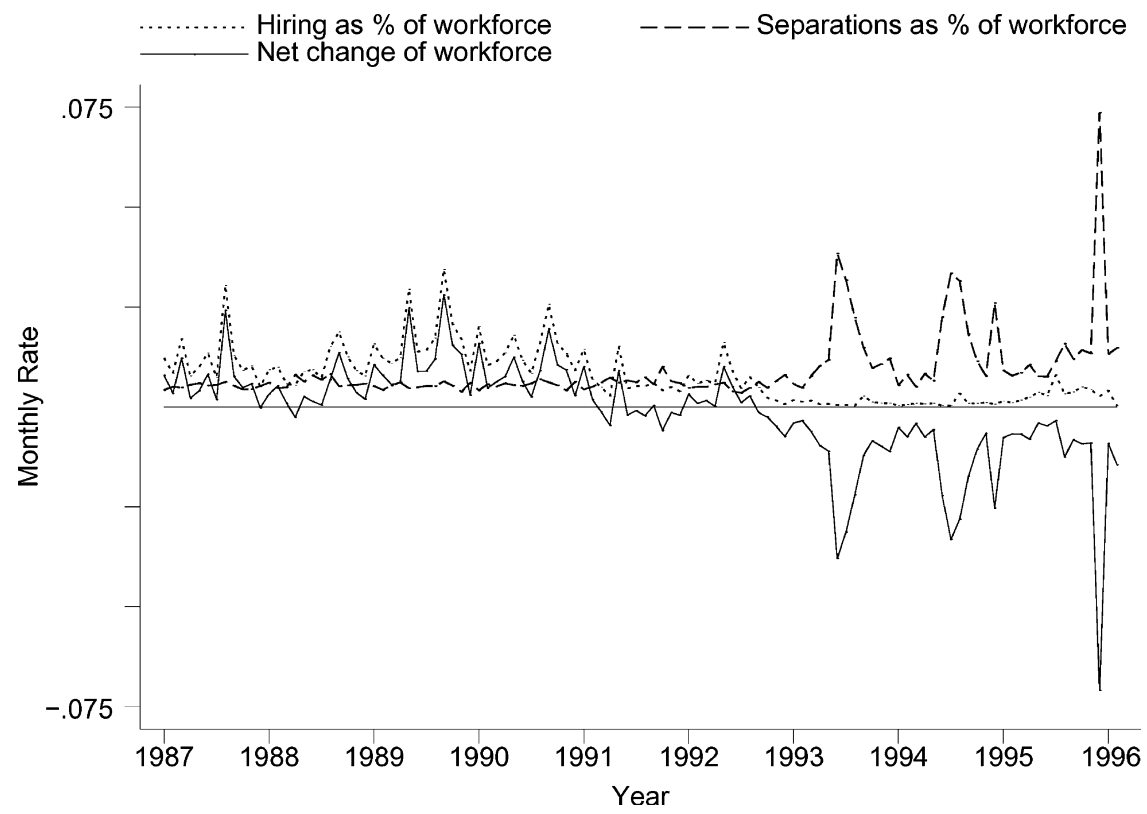

Fig. 2. Inflow, outflow, and employment growth rates. Notes: The figure plots the monthly hiring rate, the separation rate, and the net employment growth rates 
Table 3. Exit from hierarchical levels, 1987-1996

\begin{tabular}{lrrrrrrrrrr}
\hline Level & \multicolumn{1}{l}{ Year } \\
\cline { 2 - 10 } & 1987 & 1988 & 1989 & 1990 & 1991 & 1992 & 1993 & 1994 & 1995 & 1996 \\
\hline 1 & 54.0 & 49.2 & 64.0 & 66.1 & 63.7 & 63.6 & 73.4 & 60.5 & 42.2 & 43.0 \\
2 & 10.9 & 14.8 & 11.5 & 11.9 & 11.3 & 10.8 & 9.7 & 13.2 & 18.1 & 13.8 \\
3 & 8.8 & 7.7 & 4.4 & 4.4 & 6.3 & 6.6 & 5.0 & 5.9 & 7.4 & 9.5 \\
4 & 16.1 & 13.4 & 10.0 & 9.3 & 10.7 & 8.4 & 7.3 & 12.1 & 15.9 & 14.7 \\
5 & 6.4 & 6.6 & 3.2 & 3.7 & 4.9 & 5.0 & 2.1 & 4.5 & 7.4 & 9.0 \\
6 & 1.7 & 4.6 & 3.7 & 1.5 & 1.8 & 2.5 & 1.6 & 2.0 & 5.8 & 6.3 \\
7 & 1.2 & 1.5 & 1.5 & 1.3 & 0.6 & 1.7 & 0.4 & 0.7 & 1.3 & 1.8 \\
8 & 0.6 & 1.7 & 1.1 & 1.0 & 0.3 & 1.0 & 0.4 & 0.7 & 1.5 & 1.7 \\
$9-10$ & 0.3 & 0.5 & 0.6 & 0.9 & 0.3 & 0.4 & 0.2 & 0.4 & 0.4 & 0.3 \\
Total & 100.0 & 100.0 & 100.0 & 100.0 & 100.0 & 100.0 & 100.0 & 100.0 & 100.0 & 100.0 \\
\hline
\end{tabular}

Notes: The table shows for each year the percentage of separating workers that exit the firm from a given level. Levels 9 and 10 are combined for confidentiality reasons.

Exit rates are highest out of level 1 in the period of downsizing (see Table 3). Blue-collar workers, particularly those in level 1, separate first during downsizing. Exit rates from level 1 jump most during the 1993 downsizing episode, the first with mainly involuntary dismissals (see Table 3). Higher exit rates out of the bottom level of blue-collar employment can partly be ascribed to higher turnover rates among workers with short tenure who predominately entered in level 1 and separate before having made an upward transition. But even controlling for tenure and other characteristics, Dohmen and Pfann (2004) find that corporate downsizing affects exit rates of bluecollar and white-collar workers differently. While job separations are, if anything, more frequent for white-collar employees than for blue-collar workers during the period of corporate expansion, workers in the lower ranks become more likely to separate during downsizing, which is also revealed by Table 3. It is not until late 1995 that exit rates from the top 5 levels of the hierarchy increase markedly, which seems to indicate a shift in layoff policy.

\subsection{Vertical job mobility}

The fact that relative sizes of hierarchical levels remain stable during the episode of workforce expansion although entry is concentrated in the bottom levels of blue-collar and white-collar employment while exit rates are similar across levels suggests that transitions from lower to higher ranks in the hierarchy abound. In the remainder of the paper, we refer to job transitions to a higher hierarchical level as promotions and we define demotions as transitions to a lower hierarchical job level. ${ }^{12}$

We record 5704 upward moves and 1627 downward moves over the entire period which amounts to an average upward (downward) annual mobility rate of $5.6 \%(1.6 \%)$ over the entire period. ${ }^{13}$ However, 12652 workers of all the 17610 workers in our sample make no vertical transition in the hierarchy, and 7584 of them - who are mostly in level 1 (70.4\%) and rarely in levels $7-10$ $(1.7 \%)$ - have the same job code throughout while they are in the sample. Only 4543 enjoy at least one upward hierarchical transition, and 1536 
workers are demoted at least once, but a large fraction (1121 workers) belongs to both groups as they experience at least one demotion and one promotion at different times during the observation period.

Upward mobility in our firm is lower than in organizations analyzed in related studies, despite the fact that these studies are commonly based on year-end data and, therefore, miss offsetting vertical moves of stayers as well as all job changes of separating workers that take place during the year. The fact that related studies commonly consider only white-collar jobs partly explains why upward mobility is lower in our firm as a whole: Job transition rates for white-collar workers are also higher in our firm in both periods. The average annual promotion (demotion) rate for white-collar workers is $7.7 \%$ $(2.7 \%)$ during expansion and 6.4\% (2.6\%) during contraction, but $6.4 \%$ $(1.0 \%)$ during expansion and 3.9\% (1.4\%) during downsizing for blue-collar workers.

Demotions are more frequent in our firm than in the firm studied by Treble et al. (2001), and much more frequent than in the firm studied by BGH, who observe less than 200 demotions in 69840 employee years. In fact, the prevalence of downward job mobility is much more in line with the findings of Seltzer and Merrett (2000). The nature of our event history data contributes to finding a substantial number of demotions. Using year-end data (and including the cross section the day before the bankruptcy as 1996 year-end data), we would miss $27.0 \%$ of demotions and $18.7 \%$ of promotions. A substantial number of demoted workers $(12.9 \%)$ leaves the firm within a year after the downgrading. Some of these demotions potentially remain unobserved when panel data at yearly frequencies are examined. The same holds for offsetting vertical movements that occur within 365 days (but not necessarily in the same calendar year). Such temporary reassignments across job levels, which might either result from correcting previous mis-assignments or might be due to interim assignments to fill vacant positions temporarily, account for $21.6 \%$ of all demotions. The majority of such demotions offsets previous promotions. A considerable portion of such offsetting vertical job moves $(45.7 \%)$ is accounted for by workers who were promoted during expansion and demoted during downsizing. This is an interesting result because Gibbons and Waldman's (1999a) model of careers in which firms learn about employees' talents and workers accumulate productive skills would predict that the last workers promoted tend to be the least productive in their level. Dohmen (2003a) shows that the last workers promoted during an expansion phase are most likely to be demoted during a subsequent downsizing episode.

Tables 4 and 5 summarize the vertical job transition pattern for different groups of workers for the sub-periods of workforce expansion and downsizing by comparing their hierarchical position at the beginning of the period to that at the end. ${ }^{14}$ The tables are divided into four blocks. The upper two blocks contain transition patterns of workers who were employed at the beginning of the period as shares of incumbent workers, while the lower two describe transition patterns of all new entrants during the period as shares of new entrants at given entry levels during the respective period. The rows of the blocks depict what shares of workers assigned to a given level at the beginning of the period (upper blocks) - or the beginning of the employment relation for new entrants (lower blocks) - are employed in different levels at the end of the period (left blocks) and what shares left after having reached a 


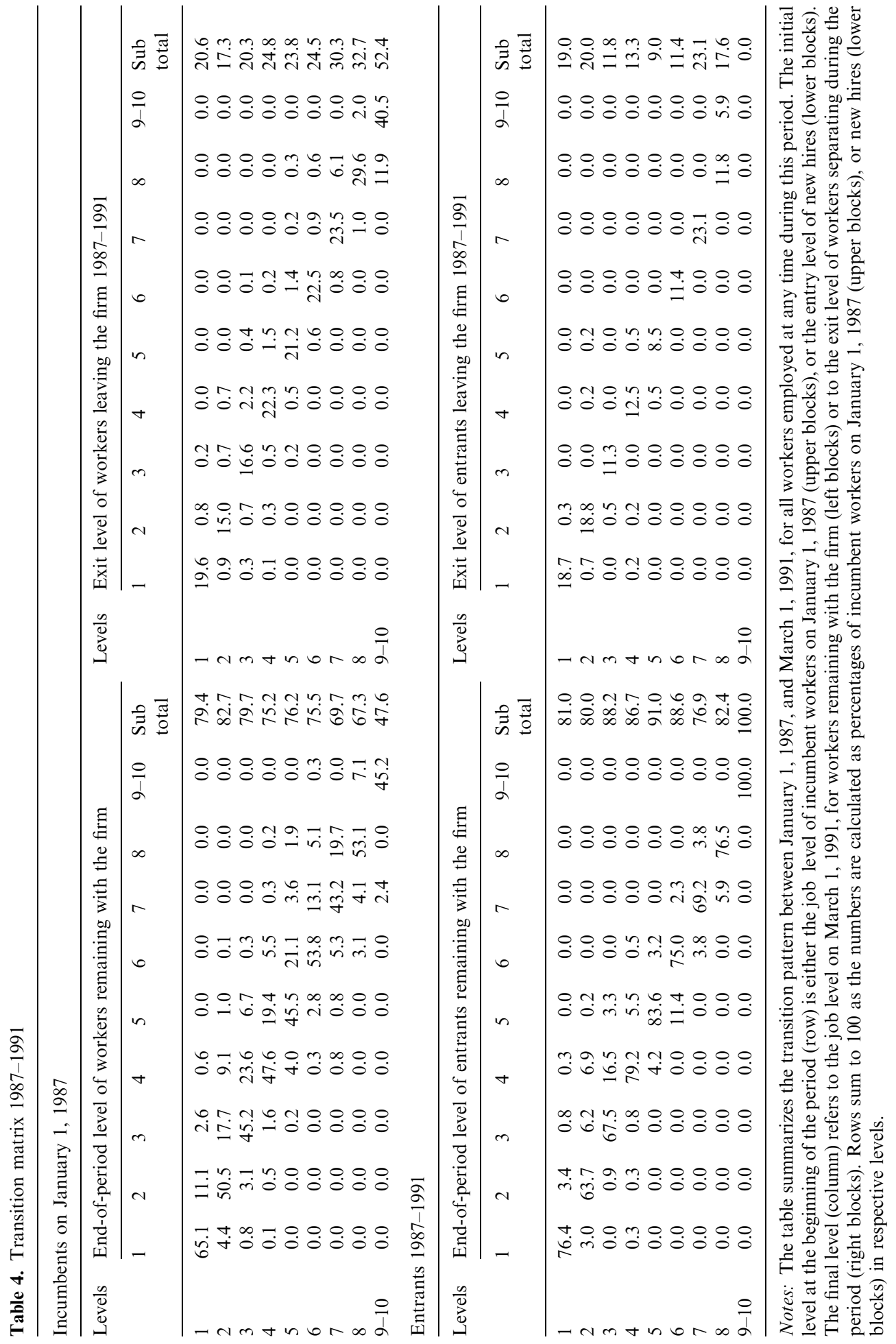




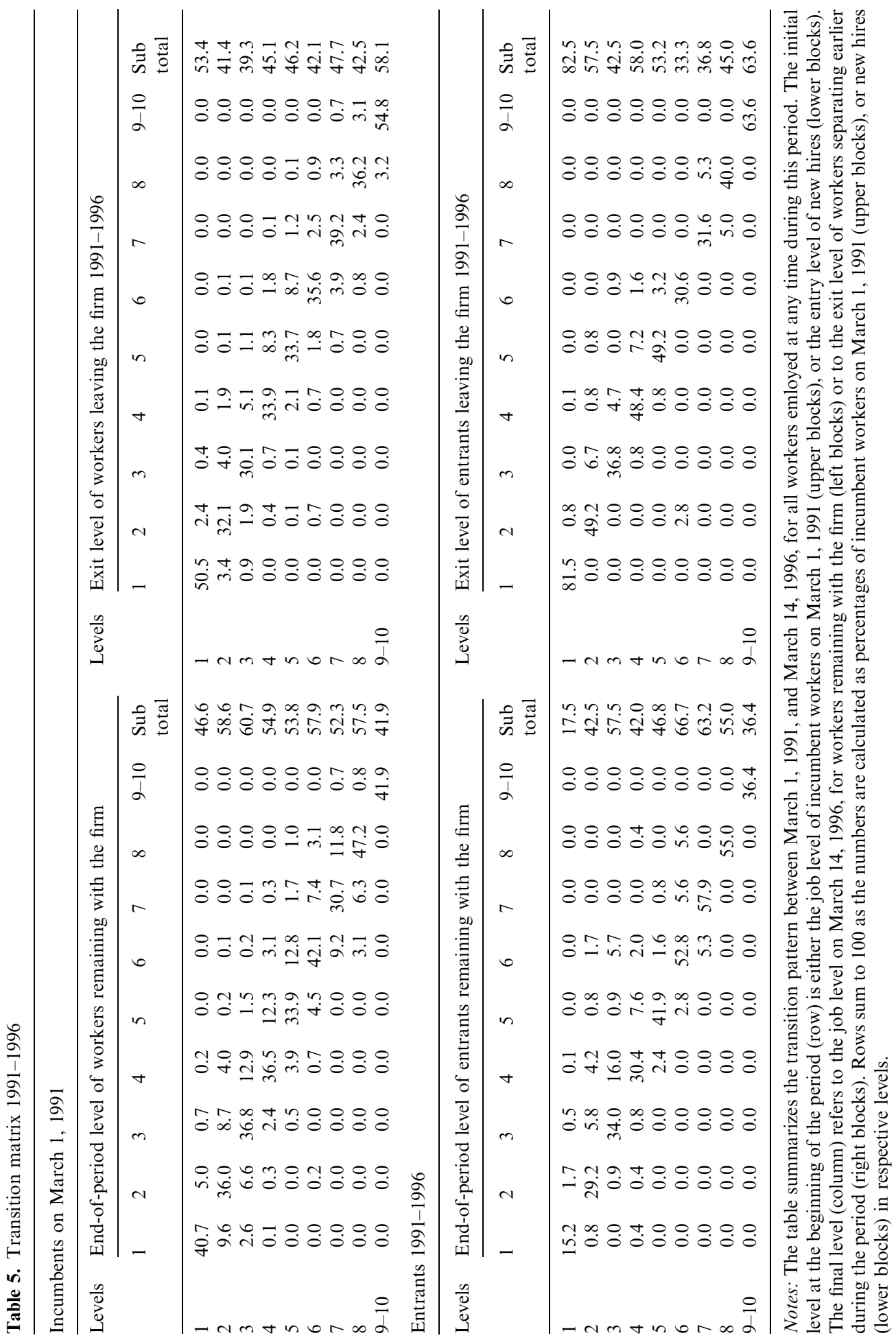


particular level (right blocks). For example, in the first period, $65.1 \%$ of all workers who were employed at level 1 on January 1, 1987, are still employed at level 1 on March 1, 1991; 11.1\% have proceeded to level 2, 2.6\% to level 3, and $0.6 \%$ to level $4 ; 20.6 \%$ separated during the period and the vast majority of them had not been promoted. Only $1 \%$ of all workers employed at level 1 at the beginning of the period had been promoted prior to their separation.

A comparison of Tables 4 and 5 reveals important facts: Firstly, a larger fraction of workers who separate in the second period had progressed to higher levels before their employment relation ends. Secondly, upward mobility is lower in the period of downsizing so that substantially fewer workers staying with the firm are promoted to higher levels. An obvious explanation is that less slots become vacant in higher positions when the company reduces employment, especially as the employment reduction is not proportional to level size. That many workers who were promoted during downsizing separate also suggests that "talented" workers leave the firm, possibly because of reduced further career prospects in a downsizing firm. More evidence that promotion rates are inversely related to exit rates comes from the fact that promotion rates fall the most for blue-collar workers, who also experience a more severe increase in separation rates. While $14.9 \%$ of all blue-collar workers and $20.0 \%$ of white-collar workers move upward in the hierarchy between January 1987 and March 1991, only 11.6\% blue-collar workers but $21.1 \%$ of white-collar workers have proceeded to a higher hierarchical positions in the longer period between March 1991 and the bankruptcy or their separation date. Consequently, relative upward mobility falls for blue-collar worker during downsizing. ${ }^{15}$

Separating workers have lower upward mobility than remaining workers, but similar downward mobility in both periods. ${ }^{16}$ Not correcting for the length of the employment spell, upward mobility rates are smaller for beginners than for the incumbent workforce. But workers who enter after January, 1987, and remain with the firm have higher upward mobility rates than entrants who separate before the end of 1991. Tables 4 and 5 also show that more workers are demoted in the second period and that a substantial fraction of them leaves. Although the downward mobility rate remains higher in the upper segment of the hierarchy downward moves become relatively more common for blue-collar workers.

The mobility pattern indicates interrelations between vertical internal job mobility and turnover rates. Upward mobility is lower during downsizing and seems to be related to the scale of workforce reductions (upward mobility falls the most in blue-collar jobs where exit is concentrated). Downward mobility is higher during periods of workforce reductions and upward mobility is positively correlated with entry rates. Fig. 3 plots the entry rate, exit rate, promotion rate and demotion rate. Not only are promotion rates higher when entry is high, but promotion rates follow entry rates in the sense that they rise when entry in the previous months had been unusually high as is evident from the period from the second half of 1988 until the beginning of downsizing in 1991. Similarly, the demotion rate usually peaks shortly before the exit rate. Finally we notice that promotion and demotion rates are positively correlated (correlation coefficient of 0.48). The graph suggests that this result is to some degree driven by the co-movement of the promotion rate and demotion rate in periods with severe employment reductions, as is reflected in the coincidence of local peaks in both rates in May 1988, January and June 1993, 


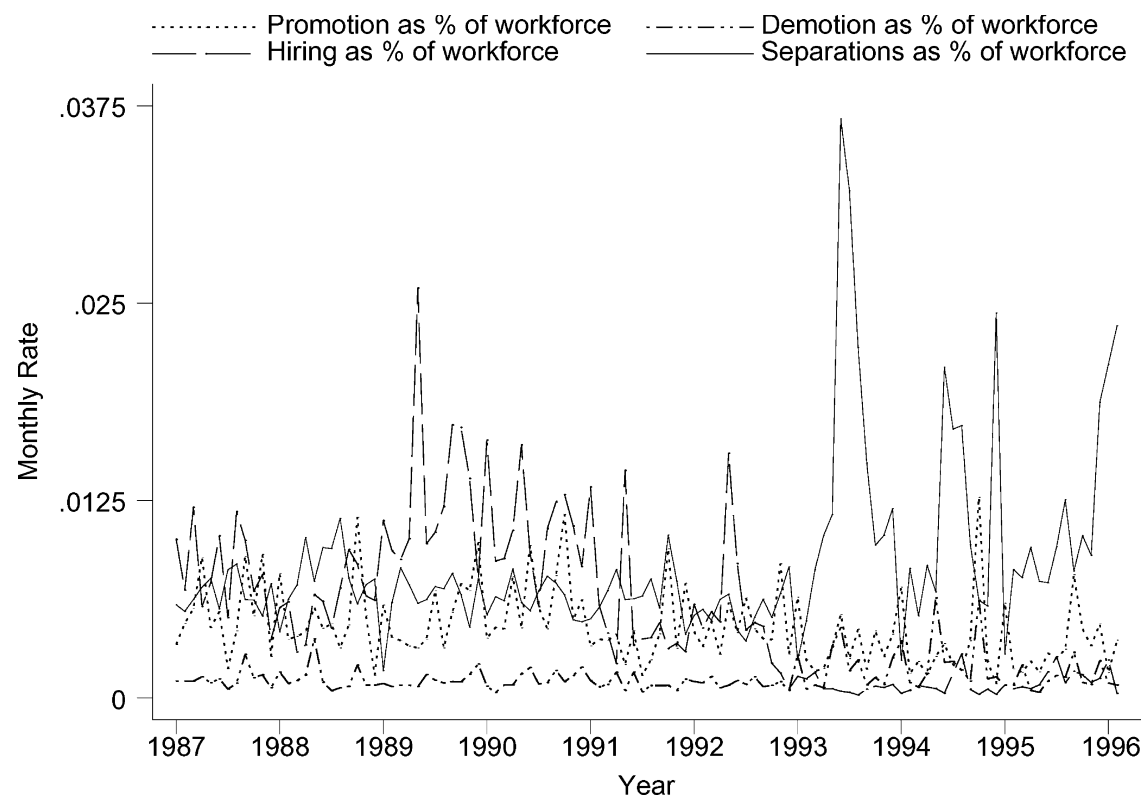

Fig. 3. Monthly mobility. Notes: The figure plots monthly promotion and demotion rates calculated as the number of transitions relative to the number of incumbent workers - along with the hiring rate and the separation rate from Fig. 2

January, May and October 1994, and September 1995. This suggests that such reorganizations trigger reassignments across job levels. The existence of a relation between changes in the size of the workforce and internal job mobility rates is an important finding that deserves more attention in theoretical work. ${ }^{17}$

\subsection{Lateral job mobility}

We observe a substantial number (13636) of lateral job transitions, which we define as changes in job codes of jobs belonging to the same hierarchical level. This is in sharp contrast to the findings of $\mathrm{BGH}$, who find that only $1.6 \%$ of all job transitions constitute lateral moves. Admittedly, some of the lateral moves that we observe are spurious job transitions due to the fact that codes might be changed over time, while the content of the job remains the same. But the largest fraction of these lateral transitions relates to changes in the job description. About one fourth of all lateral job transitions involve a transition to a different field of activity within the firm. Table 6 reports for each job level the shares of lateral transitions that involve a job change to a different field of activity.

This suggests an interesting additional dimension in the analysis of job change, promotion dynamics, and wage dynamics. Lateral transitions might occur across different fields of activities within the firm to prepare for subsequent upward mobility thereby increasing career prospects. For instance, an assembly worker might be assigned to a job in quality control or to a job in 
Table 6. Lateral job transitions to a different field of activity

\begin{tabular}{llllllllll}
\hline & \multicolumn{1}{l}{ Job level } & & & & & & \\
\cline { 2 - 8 } & 1 & 2 & 3 & 4 & 5 & 6 & 7 & 8 & $9-10$ \\
\hline $\begin{array}{l}\text { Number } \\
\%\end{array}$ & 1515 & 426 & 336 & 525 & 227 & 159 & 62 & 83 & 19 \\
\hline
\end{tabular}

Notes. This table reports for each job level the absolute number of lateral job transitions that involve a job change to a different field of activity (row 2) and their percentage share (row 3 ) of all lateral transitions at the respective level. Levels 9 and 10 are combined for confidentiality reasons.

production preparation to widen his knowledge on the entire production process which is crucial in higher level jobs. Such reassignments are usually referred to as job rotation. If the acquisition of a wider portfolio of skills that might be required in higher level jobs is the motive, the probability of an upward move increases for workers who have held different jobs at the same level. ${ }^{18}$ On the other hand, workers might be transferred laterally because they do not qualify for upward mobility. Finally, job rotation might be used to screen workers or learn about their optimal assignment (Ortega 2001), in which case lateral transitions do not entail a priori information on career perspectives. ${ }^{19}$

We assessed the impact of lateral job transitions on future promotion prospects for workers hired into the bottom hierarchical levels of blue-collar and white-collar employment (level 1 and level 4 respectively) in the following way. We constructed two variables that count the number of lateral job transitions across fields of activities in the first and second year of a new hired worker's employment relationship respectively and two variables that likewise count the number of lateral job transitions within a given field of activity during the first two years of tenure with the firm. In separate probit regression models for blue-collar and white-collar workers, we then estimated the effect of these four variables on the probability of being promoted to a higher hierarchical level during the third year of the employment relationship given that no such promotion had occurred during the first two years. ${ }^{20}$ The results indicate that lateral job mobility has a positive impact on promotion prospects for blue-collar workers, but not for white-collar workers. In fact, all coefficient estimates are insignificant for white-collar workers and only one has a positive sign. In contrast, all coefficient estimates are positive for bluecollar workers and lateral job transitions to a different field of activity have a statistically significant positive effect on a blue-collar worker's probability of being promoted two years later. Yet, the effect of such a lateral job transition is rather small: The estimated marginal effect evaluated at the mean of the explanatory variables is 0.024 such that one lateral transition to a different job activity in the first year increases a blue-collar worker's chance of being promoted in his third year by $2.4 \% .^{21}$

Hence, our results for blue-collar workers provide some weak evidence that obtaining a wider portfolio of skills by switching laterally to a different job activity improves promotion prospects. In spite of finding mostly insignificant effects of lateral transitions on the chances of promotion in the very near future we should not jump to the conclusion that lateral job transitions are not advantageous because a lateral transition might entail a career step in itself, both in terms of wage growth and in terms of job characteristics. We 
will return to this possibility in Sect. 6.3, where we analyze the relation between lateral job mobility and wage growth, and in Sect. 7.3, where we provide some evidence on career paths that involve lateral job transitions.

Furthermore, it should be noted that there is evidence that a fraction of lateral reassignments lasts only for a short time $-31 \%$ of all lateral movements are not observed in a year-end panels. This possibly results from temporarily staffing of crucial vacancies, from intended job rotation in order to learn about a worker's performance at different jobs or to stimulate the accumulation of different skills, or from correcting 'mistakes' in assignment, when an intended lateral move turns out to have resulted in an inefficient allocation.

\section{Wages and the hierarchy}

Since internal labor markets are characterized by substantial fixed costs of hiring, screening, or training, which become sunk upon a separation, internal labor markets foster long-term relations between workers and the firm. Wages no longer have to equal marginal productivity at every moment during the employment relation in presence of such fixed costs, even with competitive labor markets (see Oi 1962). Although external labor market conditions potentially constrain the internal wage structure, for example, by affecting hiring wages, competitive forces do not restrict wage determination to a unique outcome in internal labor markets. Exploiting this indeterminacy of wages, the firm can design the wage structure to encourage long-term relations, shield workers from external conditions or accomplish other goals, as, for example, the provision of incentives to elicit optimal effort levels. We analyze this wage structure in Sect. 5.2, below.

Doeringer and Piore (1971) argue that wages in internal labor markets are determined by formal, impersonal administrative procedures. Formal rules and procedures might play an important role in wage determination. Such rules might improve efficiency, for example, by solving hold-up problems, which arise when wages are set or renegotiated after firm-specific investments (e.g., including firm-specific training or broadly defined organization-specific capital, Prescott and Visscher 1980) have been made. A contractual arrangement which fixes wages in advance can serve as a commitment device and help resolve the hold-up problem (MacLeod and Malcomson 1993). Moreover, the existence of favoritism (Prendergast and Topel 1996) would give rise to rules in the wage setting process to limit discretion. Consequently, we should expect the wage structure to be governed by contractual arrangements and administrative rules.

\subsection{Administrative rules in wage setting}

The existence of wage scales at our firm provides evidence for administrative formal rules in wage setting. ${ }^{22}$ There are 10 blue-collar scales (scales 2-11) and 8 white-collar scales (scales 12-19). A range of wages exists in each white-collar wage scale. Minimum, maximum, and mean wages are increasing in subsequent scales, but wage ranges of subsequent scales overlap. $^{23}$ 


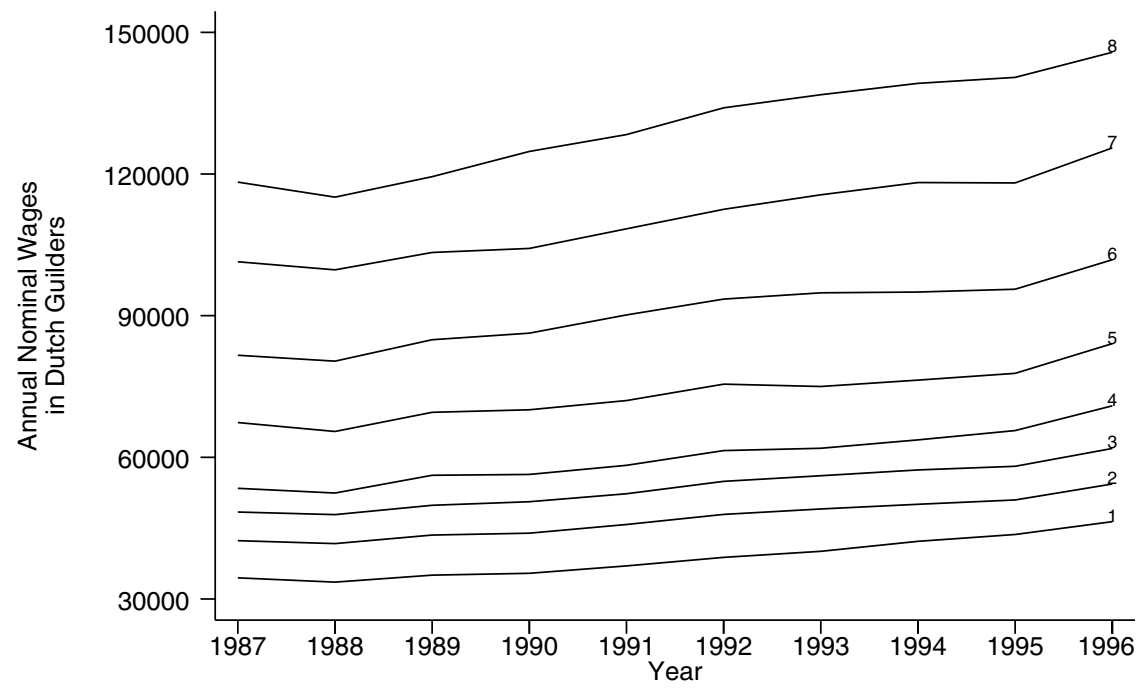

Fig. 4. Mean wage. Notes: The figure plots average full-time equivalent nominal wages of incumbent workers in the hierarchical job levels 1 through 8 , which are labelled accordingly. The thick crossed line reflects average full-time equivalent nominal wages at the firm-level. Means are calculated based on cross sections taken at the beginning of a year

All blue-collar workers are covered by collective bargaining agreements (CAO) between unions and employer federations and cover all blue-collar workers in the firm. ${ }^{24}$ The collective bargaining agreement defines, among other things, nominal wages for each of the (up to 9) wage grades within all blue-collar wage scales. ${ }^{25}$ Firms can pay above these wages, and Fokker does so. The wage grades can be interpreted as a contractual tenure-wage profile since workers commonly climb the within-scale wage ladder at distinct, mostly yearly, intervals. This structure of wage grades and wages scales is usually not changed in yearly bargaining. Instead, a percentage nominal wage increase, pertaining to all wages in blue-collar scales, is negotiated to adjust wages for aggregate conditions (e.g., inflation, technological progress, etc.). Fokker usually adjusts white-collar salaries by the same percentage, thereby shifting its entire wage frame keeping the wage structure stable.

As is common in the Netherlands (see Teulings and Hartog 1998), wage increases can be decomposed into three components: First, a worker is usually awarded a yearly raise according to the contractual experience-wage or tenure-wage profiles defined in the collective wage agreement until the highest wage in the scale is achieved. Second, contractual initial increases adjust all wages to changes in aggregate conditions. ${ }^{26}$ Third, incidental wage increases relate to any other type of wage increase including promotions. The latter type of wage contract changes might occur throughout the year, but the bulk of wage changes, pertaining to collectively negotiated wage adjustments or contractual periodical increases take place at the turn of the year and are usually administered in our data set in the last week of December or the first week of January. 


\subsection{Job levels and wages}

The correlation between job levels and salary scales $(0.92$ in the entire sample, or 0.68 and 0.81 in the blue-collar and white-collar scales respectively) indicates a strong relation between wages and jobs. This is confirmed by Fig. 4 which plots mean nominal full-time equivalent within-job-level wages over time. ${ }^{27}$ The vertical wage structure is remarkably stable throughout in the sense that the magnitude of differences in average wages between job levels persists. Only average nominal wages in levels 1 and 4 rise somewhat faster during downsizing mainly because of the entry and exit patterns that change the within-level wage distribution. Table 7 illustrates, for example, that new hires predominately start off in the lowest decile of the within-level wage distribution. ${ }^{28} \mathrm{~A}$ considerable fraction of separating workers also comes from the lower deciles of the wage distribution (see Table 8), so that average within-level wages increase when the hiring rate falls and the separation rate rises.

Table 7. Distribution of pay for new hires in wage deciles

\begin{tabular}{|c|c|c|c|c|c|c|c|c|c|c|c|c|}
\hline \multicolumn{13}{|c|}{ 1987-1991 } \\
\hline \multirow[t]{2}{*}{ Level } & \multirow[t]{2}{*}{$\mathrm{N}$} & \multicolumn{10}{|c|}{ Decile in job level wage distribution } & \multirow[t]{2}{*}{ All } \\
\hline & & $1 \mathrm{st}$ & 2 nd & $3 \mathrm{rd}$ & 4 th & 5 th & 6 th & 7 th & 8 th & 9 th & Top & \\
\hline 1 & 4270 & 33.1 & 20.0 & 16.9 & 14.2 & 7.7 & 4.2 & 2.5 & 0.7 & 0.6 & 0.2 & 100.0 \\
\hline 2 & 405 & 52.1 & 22.7 & 8.4 & 4.0 & 2.5 & 3.7 & 1.5 & 1.0 & 2.2 & 2.0 & 100.0 \\
\hline 3 & 212 & 49.5 & 9.4 & 17.9 & 10.4 & 4.2 & 3.3 & 1.4 & 0.9 & 0.9 & 1.9 & 100.0 \\
\hline 4 & 602 & 35.5 & 18.4 & 22.8 & 6.3 & 4.7 & 2.8 & 3.0 & 2.7 & 2.3 & 1.5 & 100.0 \\
\hline 5 & 189 & 53.4 & 9.0 & 9.5 & 6.3 & 2.6 & 4.2 & 5.8 & 0.5 & 4.2 & 4.2 & 100.0 \\
\hline 6 & 45 & 33.3 & 13.3 & 4.4 & 20.0 & 6.7 & 4.4 & 2.2 & 2.2 & 6.7 & 6.7 & 100.0 \\
\hline 7 & 24 & 20.8 & 25.0 & 12.5 & 4.2 & 0.0 & 12.5 & 4.2 & 16.7 & 4.2 & 0.0 & 100.0 \\
\hline 8 & 12 & 25.0 & 0.0 & 16.7 & 0.0 & 8.3 & 25.0 & 0.0 & 0.0 & 0.0 & 25.0 & 100.0 \\
\hline \multicolumn{13}{|c|}{ 1991-1996 } \\
\hline \multirow[t]{2}{*}{ Level } & \multirow[t]{2}{*}{$\mathrm{N}$} & \multicolumn{10}{|c|}{ Decile in job level wage distribution } & \multirow[t]{2}{*}{ All } \\
\hline & & $1 \mathrm{st}$ & 2nd & $3 \mathrm{rd}$ & 4 th & 5 th & 6 th & 7 th & 8 th & 9 th & Top & \\
\hline 1 & 926 & 58.9 & 18.3 & 9.9 & 5.1 & 3.6 & 1.4 & 1.3 & 1.1 & 0.2 & 0.3 & 100.0 \\
\hline 2 & 111 & 35.1 & 16.2 & 14.4 & 7.2 & 8.1 & 5.4 & 4.5 & 5.4 & 0.9 & 2.7 & 100.0 \\
\hline 3 & 102 & 58.8 & 9.8 & 10.8 & 6.9 & 2.0 & 2.0 & 2.9 & 1.0 & 1.0 & 4.9 & 100.0 \\
\hline 4 & 243 & 43.6 & 33.3 & 7.0 & 3.3 & 3.3 & 0.8 & 1.2 & 3.7 & 2.1 & 1.6 & 100.0 \\
\hline 5 & 120 & 76.7 & 8.3 & 6.7 & 3.3 & 0.0 & 0.8 & 1.7 & 0.8 & 0.8 & 0.8 & 100.0 \\
\hline 6 & 31 & 35.5 & 16.1 & 6.5 & 9.7 & 0.0 & 0.0 & 3.2 & 6.5 & 6.5 & 16.1 & 100.0 \\
\hline 7 & 14 & 21.4 & 7.1 & 14.3 & 7.1 & 0.0 & 14.3 & 7.1 & 0.0 & 0.0 & 28.6 & 100.0 \\
\hline 8 & 9 & 11.1 & 0.0 & 22.2 & 0.0 & 11.1 & 0.0 & 22.2 & 0.0 & 22.2 & 11.1 & 100.0 \\
\hline
\end{tabular}

Notes: The two blocks of the table show for the periods from January 1, 1987, until March 1, 1991 (upper block), and from March 1, 1991, until March 14, 1996 (lower block), the number of entrants into each level (column 2). Columns 3-12 of the blocks show the percentage shares of workers entering in a given job level whose starting wage is in a particular decile of the respective job level wage distribution. Wage distributions are based on hourly wages for all workers employed in the relevant job level and period and are calculated on the dates following contract wage adjustments due to inflation compensation and (semi-)annual raise. For privacy reasons, there is no salary information for levels 9 and 10 in the personnel files. 
Such changes in within-level wage distributions explain why average nominal job level wages - especially in levels 1 and 4 (see Fig. 4) where exit is concentrated and hiring falls the most - rise after 1993 although it was agreed in collective bargaining not to adjust wage scales at the firm for inflation because of the firm's depressed economic condition. Such inflation corrections remained eventually set out until January 1, 1996, when they were made up for. However, the rise in average firm-level wages can be mainly attributed to the rise in the employment share in higher hierarchical levels resulting from the relative lower separation rates of high-wage workers discussed in Sect. 4.1.

Separating workers are more evenly distributed over the wage distribution than new hires (compare Tables 7 and 8). A substantial fraction of workers moves up in the job-level wage distribution before separating. This provokes the question of how big the spread in job-level wage distributions is, i.e., how much wage growth is associated with moving up a decile in the job-level wage distribution. Kernel density estimates of the within-level wage distributions in Fig. 5 reveal substantial wage variation. The wage distributions in the figure

Table 8. Distribution of pay for separating workers in wage deciles

\begin{tabular}{|c|c|c|c|c|c|c|c|c|c|c|c|c|}
\hline \multicolumn{13}{|c|}{$1987-1991$} \\
\hline \multirow[t]{2}{*}{ Level } & \multirow[t]{2}{*}{$\mathrm{N}$} & \multicolumn{10}{|c|}{ Decile in job level wage distribution } & \multirow[t]{2}{*}{ All } \\
\hline & & $1 \mathrm{st}$ & 2 nd & $3 r d$ & 4 th & 5 th & 6 th & 7 th & 8 th & 9 th & Top & \\
\hline 1 & 1835 & 11.0 & 15.5 & 15.9 & 11.9 & 11.1 & 10.1 & 6.7 & 6.0 & 5.4 & 6.4 & 100.0 \\
\hline 2 & 376 & 19.4 & 12.5 & 10.1 & 6.9 & 6.6 & 4.5 & 8.5 & 7.7 & 9.3 & 14.4 & 100.0 \\
\hline 3 & 202 & 17.8 & 10.9 & 6.9 & 6.9 & 4.0 & 6.9 & 5.0 & 8.9 & 13.4 & 19.3 & 100.0 \\
\hline 4 & 356 & 17.1 & 10.7 & 9.8 & 7.0 & 7.9 & 5.9 & 10.7 & 8.7 & 5.6 & 16.6 & 100.0 \\
\hline 5 & 172 & 16.3 & 8.1 & 8.1 & 10.5 & 12.2 & 5.2 & 7.0 & 4.1 & 14.0 & 14.5 & 100.0 \\
\hline 6 & 92 & 15.2 & 12.0 & 12.0 & 8.7 & 7.6 & 9.8 & 6.5 & 7.6 & 5.4 & 15.2 & 100.0 \\
\hline 7 & 42 & 9.5 & 11.9 & 7.1 & 4.8 & 7.1 & 9.5 & 9.5 & 7.1 & 9.5 & 23.8 & 100.0 \\
\hline 8 & 31 & 3.2 & 3.2 & 3.2 & 12.9 & 3.2 & 6.5 & 19.4 & 6.5 & 25.8 & 16.1 & 100.0 \\
\hline \multicolumn{13}{|c|}{$1991-1996$} \\
\hline \multirow[t]{2}{*}{ Level } & $\mathrm{N}$ & \multicolumn{10}{|c|}{ Decile in job level wage distribution } & \multirow[t]{2}{*}{ All } \\
\hline & & $1 \mathrm{st}$ & 2nd & $3 \mathrm{rd}$ & 4 th & 5 th & 6th & 7 th & 8th & 9th & Top & \\
\hline 1 & 4271 & 16.1 & 13.6 & 13.0 & 11.9 & 10.0 & 8.7 & 7.0 & 4.6 & 8.2 & 7.0 & 100.0 \\
\hline 2 & 865 & 13.8 & 11.4 & 10.8 & 9.7 & 7.3 & 8.6 & 9.8 & 6.0 & 9.2 & 13.4 & 100.0 \\
\hline 3 & 484 & 14.5 & 11.0 & 8.1 & 8.7 & 9.3 & 3.1 & 10.5 & 14.0 & 5.6 & 15.3 & 100.0 \\
\hline 4 & 765 & 12.9 & 13.5 & 10.6 & 8.5 & 7.2 & 6.1 & 10.7 & 8.8 & 3.8 & 17.9 & 100.0 \\
\hline 5 & 502 & 14.1 & 13.3 & 10.0 & 8.0 & 11.2 & 8.4 & 6.0 & 2.2 & 15.9 & 11.0 & 100.0 \\
\hline 6 & 287 & 11.5 & 12.2 & 8.7 & 11.5 & 7.7 & 1.0 & 10.5 & 9.8 & 10.5 & 16.7 & 100.0 \\
\hline 7 & 92 & 12.0 & 10.9 & 12.0 & 3.3 & 20.7 & 5.4 & 6.5 & 1.1 & 7.6 & 20.7 & 100.0 \\
\hline 18 & 66 & 7.6 & 10.6 & 6.1 & 6.1 & 12.1 & 6.1 & 13.6 & 3.0 & 28.8 & 6.1 & 100.0 \\
\hline
\end{tabular}

Notes: The two blocks of the table show for the periods from January 1, 1987, until March 1, 1991 (upper block), and from March 1, 1991, until March 14, 1996 (lower block), the number of exists from each level (column 2). Columns 3-12 of the blocks show the percentage shares of workers existing from a given job level whose final wage is in a particular decile of the respective job level wage distribution. Wage distributions are based on hourly wages for all workers employed in the relevant job level and period and are calculated on the dates following contract wage adjustments due to inflation compensation and (semi-)annual raises. Only the first accession to the firm of a worker is considered, so that re-hiring is neglected. For privacy reasons, there are no salary information for levels 9 and 10 in the personnel files. 


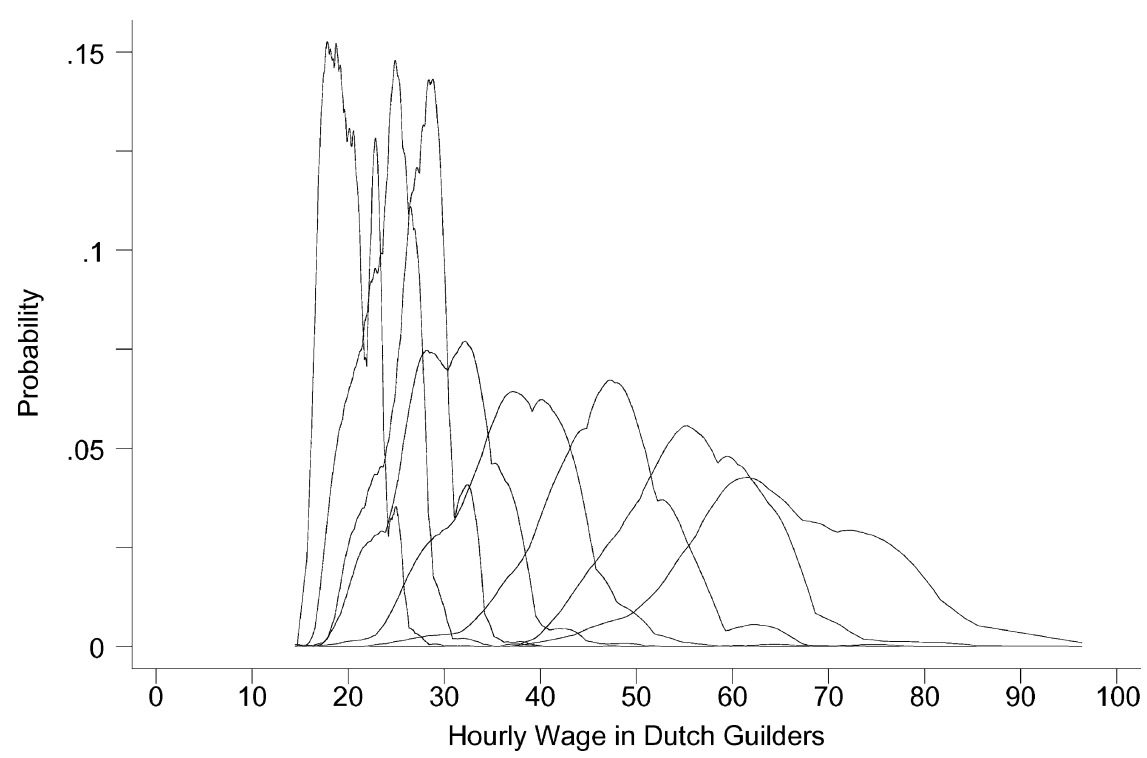

Fig. 5. Wage spread by job levels in 1991. Notes: The figure plots kernel density estimates of the within job-level distribution of hourly full-time equivalent wages on March 14, 1991. Observed annual wages are truncated at 200,000 Dutch Guilders. This truncation affects only very few workers in level 8 , but should not bias estimates of the wage distribution in level 8 significantly

refer to 1991, but their main features are the same in all years ${ }^{29}$ : Wages rise on average with job-levels, but wage distributions of successive hierarchical levels overlap. Wages are definitely related to job levels as the correlation between job levels and wage scales already suggested, but wages are not tied to jobs in a strict sense as substantial within-job-level wage variation remains. These results are in line with $\mathrm{BGH}$ findings. However, the relation between wages and hierarchical levels is less convex in our firm than in the BGH firm. Whereas BGH find a convex relation even between the logarithm of wages and job levels, we only find a convex relation between the average wage level and job levels (cf., Table 9).

Tournament models (e.g., Lazear and Rosen 1981; Rosen 1986) and hierarchy models (e.g., Calvo and Wellisz 1979; Rosen 1982) predict that wage differences between hierarchical levels increase towards the top of the hierarchy. In hierarchical sorting models (e.g., Rosen 1982), a convex relation between wages and job levels stems from a scale effect that arises because more talented workers are assigned to higher hierarchical positions, where their decisions raise the productivity of all subordinated workers. The sequential tournament model (Rosen 1986), in which workers compete for sequential promotions along a corporate job ladder, also predicts a convex relation between wages and job levels because the inter-job-level wage spread jumps at the top of the hierarchy when there is no option value of additional future promotions. At lower levels, part of the winner's prize includes the possibility to compete for even larger prizes. Unfortunately, we do not observe wages for workers in the two top levels. How convex the relation between wages and job levels is, and whether there is even a convex relation 
Table 9. Salary premium of promotion

\begin{tabular}{|c|c|c|c|c|c|c|}
\hline \multirow[t]{3}{*}{ Level } & \multicolumn{3}{|l|}{ 1987-1991 } & \multicolumn{3}{|l|}{ 1991-1996 } \\
\hline & \multicolumn{2}{|c|}{ Premium (\%) } & \multirow{2}{*}{$\begin{array}{l}\% \text { diff. } \\
\text { means }\end{array}$} & \multicolumn{2}{|c|}{ Premium (\%) } & \multirow{2}{*}{$\begin{array}{l}\% \text { diff. } \\
\text { means }\end{array}$} \\
\hline & Immediate & Later & & Immediate & Later & \\
\hline $1-2$ & $4.7(2.4)$ & $2.7(2.1)$ & 24.4 & $4.4(2.7)$ & $2.9(1.9)$ & 20.4 \\
\hline $2-3$ & $4.4(2.2)$ & $3.1(2.3)$ & 14.8 & $4.4(2.4)$ & $2.9(1.8)$ & 14.4 \\
\hline $3-4$ & $5.4(4.3)$ & $3.1(3.0)$ & 10.7 & $4.9(3.1)$ & $3.7(2.4)$ & 12.1 \\
\hline $4-5$ & $5.7(3.1)$ & $3.7(2.7)$ & 24.6 & $5.6(3.5)$ & $3.4(1.9)$ & 20.6 \\
\hline $5-6$ & $5.6(2.4)$ & $3.2(2.3)$ & 23.0 & $6.3(7.0)$ & $3.4(2.2)$ & 24.4 \\
\hline $6-7$ & $6.5(4.2)$ & $3.2(1.9)$ & 22.9 & $8.4(10.9)$ & $2.6(1.9)$ & 21.8 \\
\hline $7-8$ & $8.3(6.9)$ & $1.8(1.8)$ & 15.9 & $8.5(11.4)$ & $2.9(1.9)$ & 18.5 \\
\hline Total & $5.2(3.3)$ & $3.1(2.5)$ & 19.5 & $5.2(4.9)$ & $3.2(2.1)$ & 18.9 \\
\hline
\end{tabular}

Notes:

1. The table shows salary premiums as percentage gains relative to the wage before the promotion. Workers either receive a wage increase on the day of promotion (immediate) or in the months following the promotion (later).

2. Average premiums are calculated for both groups separately and are reported in the columns labelled "immediate" and "later". The columns labelled "o diff. Means" reports the percentage difference between the mean wage of adjacent job levels. Standard deviations are printed in parentheses below the means.

3. The difference in level 7 and level 8 mean wages is, of course, an underestimate of the true difference since wages of some workers in level 8 are not reported as the distribution of reported wages is truncated at 200,000 guilders.

4. For privacy reasons, there are no salary information for levels 9 and 10 in the personnel files.

between the logarithm of wages and job levels, depends on a number of factors, including the time horizon of worker careers, discounting, and especially on the number of contestants at each sequence as well as the degree of risk aversion of participants. If workers are sufficiently risk averse, an incentive-maintaining prize structure requires a weakly convex relation between the logarithm of wages and job levels. However, we do not find that inter-level percentage wage differences increase towards the top of the hierarchy - in contrast, percentage wage differences between levels even narrow towards the top of the blue-collar ranks (see Table 9). Since we cannot control for risk aversion of workers and other relevant factors, it is difficult to make decisive statements about the consistency of our observed vertical wage structure and tournament theory. We sense however, that the wage structure provides at best only weak evidence for tournaments, not least because standard tournament models do not predict the substantial amount of withinlevel wage variation that we observe.

Wage differentials for individuals in the same job can result in a model with deferred compensation (Lazear 1979). But in our firm, only part of the within-job-level wage spread is explained by tenure. Gibbons and Waldman (1999a) propose an alternative explanation for within-job-level wage spread, which seems to be consistent with our findings. In their model, workers have different abilities that determine the rate of skill acquisition on the job. As they improve their productivity, they climb the within-job-level wage ladder. Firms that learn about their employees' talents assign a worker to a higher job level once his expected productivity exceeds a certain threshold value. In 
an extension of this model, Gibbons and Waldman (2003) introduce worker heterogeneity in schooling, which allows them to predict overlapping wage ranges in adjacent job levels. This holds for our firm as well.

Within-level wage variation generally increases in hierarchical levels. ${ }^{30}$ Wage distributions for blue-collar job levels have a markedly smaller variance. This disparity in the pay structure results most likely from more stringent formal rules in blue-collar wage setting as a consequence of collective bargaining. The higher wage variation for white-collar workers suggests that there is scope for individual negotiation in spite of the formal wage system.

Still, the existence of pay ranges for jobs indicates that such scope is limited, certainly for blue-collar workers. For example, 99\% of assembly workers' wage contracts (the largest job code) are in wage scales 4-8 (95\% are in 5-8). Within that pay range, individual wages depend on experience and tenure. The tenure-wage profile, however, is again governed by the contractual wage system. The firm seems to have some discretion to reward workers below the top of the within-job pay range with higher wage growth by awarding more than 1 periodical increase at a time or granting a wage in a higher wage scale. However, once the highest wage in the job has been reached, additional wage growth - beyond wage adjustments to aggregate conditions as fixed in collective bargaining agreements - can only result from job change. ${ }^{31}$

\section{Wage growth and job transitions}

\subsection{Wages and promotions}

Since wages are positively correlated with hierarchical levels, we expect wages to rise upon promotion. The large difference in mean job-level wages unveiled by Fig. 4 might suggest that promoted workers enjoy substantial wage gains. On the other hand, Fig. 5 shows that wage distributions of successive levels overlap so that promotions might not be associated with nominal wage increases at all. We find that wage contracts are changed simultaneously with upward transitions in $51.6 \%$ of the cases. Nominal wages rise in these cases by an average of $5.2 \%$ and these upward job transition are mostly (in $72 \%$ of the cases) associated with climbing at least one wage scale. Wage changes for the majority of the remaining $48.4 \%$ of upward movers occur within 3 months after the upward job transition. ${ }^{32}$ However, fewer of them $(29.9 \%)$ proceed to a higher wage scale, and their wages grow by less on average (3.1\%). Table 9 discloses that average wage increases upon promotions are substantially lower than the gap between mean wages of successive levels in both periods and for all levels. 33

This observation triggers the conjecture that workers only receive a new job title in order to grant them additional wage growth when they have reached the upper range of wages in their current job, which implies that workers are always promoted out of the top decile of their job-level wage distribution. Table 10 shows for each level what fraction of workers was promoted out of a given decile of that level's wage distribution and how promoted workers are distributed in the new level's wage distribution. The table illustrates that promoted workers were predominantly, but not exclu- 
Table 10. Distribution of pay for promotees in salary deciles before and after promotions

\begin{tabular}{lrrrrrrrrrrr}
\hline & Bottom & 2nd & 3rd & 4th & 5th & 6th & 7th & 8th & 9th & Top & All \\
\hline Level 1 before promotion & 2.0 & 4.0 & 6.7 & 9.3 & 11.5 & 11.2 & 10.3 & 14.3 & 11.4 & 19.3 & 100.0 \\
Level 2 after promotion & 27.7 & 19.7 & 16.3 & 12.1 & 9.9 & 6.5 & 3.2 & 2.5 & 1.4 & 0.7 & 100.0 \\
Level 2 before promotion & 3.5 & 7.3 & 9.4 & 8.6 & 8.9 & 7.5 & 9.2 & 15.2 & 10.7 & 19.6 & 100.0 \\
Level 3 after promotion & 18.4 & 17.8 & 15.6 & 18.0 & 11.6 & 8.4 & 4.5 & 2.6 & 2.1 & 1.2 & 100.0 \\
Level 3 before promotion & 7.6 & 10.7 & 9.5 & 10.4 & 8.3 & 6.6 & 9.8 & 9.0 & 15.1 & 13.0 & 100.0 \\
Level 4 after promotion & 10.5 & 15.4 & 15.6 & 17.6 & 16.6 & 9.7 & 7.9 & 3.6 & 1.8 & 1.4 & 100.0 \\
Level 4 before promotion & 3.2 & 5.5 & 7.9 & 8.6 & 9.4 & 9.2 & 9.6 & 13.5 & 15.9 & 17.2 & 100.0 \\
Level 5 after promotion & 17.6 & 21.4 & 17.7 & 16.4 & 12.3 & 7.5 & 2.7 & 1.6 & 1.9 & 1.0 & 100.0 \\
Level 5 before promotion & 2.5 & 5.6 & 7.0 & 10.1 & 9.9 & 11.0 & 14.3 & 9.3 & 11.8 & 18.4 & 100.0 \\
Level 6 after promotion & 29.2 & 25.3 & 16.8 & 8.9 & 8.1 & 2.3 & 3.5 & 3.1 & 1.9 & 1.0 & 100.0 \\
Level 6 before promotion & 3.9 & 4.6 & 9.9 & 9.2 & 11.8 & 5.9 & 11.2 & 11.8 & 13.2 & 18.4 & 100.0 \\
Level 7 after promotion & 36.2 & 23.7 & 9.2 & 7.2 & 13.2 & 5.9 & 0.0 & 2.6 & 0.7 & 1.3 & 100.0 \\
Level 7 before promotion & 1.3 & 8.8 & 3.8 & 8.8 & 8.8 & 12.5 & 10.0 & 16.3 & 6.3 & 23.8 & 100.0 \\
Level 8 after promotion & 16.3 & 21.3 & 13.8 & 7.5 & 18.8 & 10.0 & 7.5 & 2.5 & 1.3 & 1.3 & 100.0 \\
\hline
\end{tabular}

Notes: 'The table shows percentage shares of promoted workers' wages across deciles of the respective job level wage distribution before and after their promotion. Wage distributions are based on hourly wages for all workers employed in the relevant job level and period. We calculated the wage deciles of the current wage distribution on different dates on which the bulk of wage contracts were adjusted, e.g. because of (semi-)annual inflation compensation, during the period. The Table only summarizes information of workers promoted to the next higher level. For privacy reasons, there are no salary information for levels 9 and 10 in the personnel files.

sively, in the upper deciles of their previous level wage distribution and mostly earn below median wages in their new job-level. These results are consistent with the empirical findings of $\mathrm{BGH}$. In a more detailed analysis than is documented in Table 10, we find that workers promoted out of the bottom three deciles of their job level wage distribution move predominately to the lowest decile of the wage distribution in the new job, workers from the 4th and 5th decile move predominately to the 2 nd decile, from the 6th and 7 th decile to the 3rd decile, and from the 8th, 9th, and 10th decile to the 4th, 5th, and 6th decile respectively. The transitions in the wage distributions of promoted workers are remarkably similar in both periods. We interpret this as evidence that the principal reason for a vertical job transition is not to merely grant higher wages but to assign workers to more complex jobs with more responsibility or span of control.

We find evidence that wage growth rates are persistent. For every year, we calculated the wage growth distribution separately. Workers with wage growth in the upper (lower) quartile of the wage growth distribution are likely to be in the upper (lower) quartile in subsequent years. Regression results (cf., Table 11) show a positive effect of lagged wage growth on current wage growth (column 2) even if we control for recent promotions (column 3). This strong effect disappears if we control for the concavity of the tenure-wage profile, for individual characteristics, such as age, education and performance, and for job characteristics (column 4). ${ }^{34}$

Again, our results concerning the relation between wages and upward job transitions do not provide strong support for the tournament model as described by Lazear and Rosen (1981) and Rosen (1986). Immediate wage increases upon promotions seem much smaller than tournament theory would predict (see Table 9). However, the present value of a promotion substantially exceeds the value associated with the immediate wage gain 
Table 11. Serial correlation in wage growth

\begin{tabular}{llll}
\hline & \multicolumn{2}{l}{ Dependent variable: $\Delta \ln (W)$} & \\
\hline$\Delta \ln (W)_{t-1}$ & $0.424(0.017)^{*}$ & $0.416(0.017)^{*}$ & $-0.013(0.006)$ \\
Promotion & & $0.033(0.001)^{*}$ & $0.026(0.001)^{*}$ \\
$\begin{array}{l}\text { Promotion } \\
\text { Controls for individual }\end{array}$ & No & $-0.001(0.001)$ & $0.005(0.000)^{*}$ \\
$\begin{array}{l}\text { characteristics } \\
\text { Year dummies }\end{array}$ & Yes & No & Yes \\
Observations & 75772 & Yes & Yes \\
R-squared & 0.36 & 75772 & 75772 \\
\hline
\end{tabular}

Notes:

1. The dependent variable in all estimations is the log differences of annual hourly wages $(\Delta \ln (W))$.

2. Reported coefficients are marginal effects evaluated at the mean of the explanatory variables.

3. Standard errors are in parentheses. An asterisk denotes that the coefficient is significant at the 1 percent level.

4. Controls for individual characteristics include binary variables for nine education categories, yearly age dummies, tenure, dummies for hierarchical levels, and binary variables for the six performance evaluation scores.

Table 12. Promotion and wage growth

\begin{tabular}{llll}
\hline & \multicolumn{2}{l}{ Dependent variable: promotion } \\
\hline $\begin{array}{l}\Delta \ln (W)_{t-1} \\
\text { Promotion } t-1\end{array}$ & $0.413(0.045)^{*}$ & $0.719(0.062)^{*}$ & $-0.101(0.06)$ \\
$\begin{array}{l}\text { Controls for individual } \\
\text { characteristics }\end{array}$ & No & $-0.088(0.003)^{*}$ & $-0.08(0.003)^{*}$ \\
Year dummies & Yes & Yes \\
Observations & 39728 & Yes & Yes \\
\hline
\end{tabular}

Notes:

1. The dependent variable in all estimations is a binary variable indicating a promotion.

2. $\Delta \ln (W)$ denotes the $\log$ differences of annual hourly wages.

3. Reported coefficients are marginal effects evaluated at the mean of the explanatory variables.

4. Standard errors are in parenthesis.

5. An asterisk denotes that the coefficient is significant at the $1 \%$ level.

6. Controls for individual characteristics include binary variables for nine education categories, yearly age dummies, tenure, and binary variables for the six performance evaluation scores.

because the upward transition yields the perspective of additional future wage growth when the promoted worker moves up towards the new job level's wage ceiling. Gibbons and Waldman's (1999a) model squares much better with the empirical findings concerning the relation between wage dynamics and job transitions, as it predicts that promotions coincide with relatively high wage growth, but that wages also grow in the new job level in the years following the promotion. Besides, their model predicts promotion fast-tracks.

This raises the question of whether wage increases predict promotions as workers who are candidates for higher level positions might already be rewarded for better than average performance by higher than usual wage increases in their current job. Moreover, if promotion fast tracks (Rosenbaum 
1984) exist and if promotions are associated with wage growth (see previous section), past wage increases should identify career movers and predict future promotions. In order to test the predictive power of previous wage increases for a promotion, we estimate probit models in cross sections of the data, in which promotions are explained by past wage growth, and individual characteristics. The results reported in Table 12 show that past wage growth has a positive effect on the probability to be promoted (column 2 and 3), but that this effect works through the impact of individual characteristics on wage growth, as the direct effect of wage growth on promotion probability disappears if we include controls for tenure, age, education, and performance evaluation (column 4).

\subsection{Wages and demotions}

The logic of the previous section, which established that promotions are associated with nominal (and real) wage growth, suggests wage cuts at demotions. However, consistent with Bewley's (1999) findings, nominal wage cuts are extremely rare even during downsizing. The firm might be reluctant to cut wages because workers perceive a wage cut as unfair and reduce effort as survey evidence by Blinder and Choi (1990) suggests. ${ }^{35}$

Only 197 nominal hourly wage rate cuts are recorded, which amounts to 0.1 percent of all wage contract changes. ${ }^{36}$ Ninety percent of those experiencing nominal cuts remain in the same function. Moreover, most nominal wage cuts (117 out of 197) occur between January 1993 and January 1995 and are concentrated (105 out of 117) at a single plant (ELMO). ${ }^{37}$ The absolute number of observed wage cuts would obviously be smaller if we had data at yearly frequency due to attrition and within-year contract changes. ${ }^{38}$

Real wage cuts are more frequent during downsizing. In 1994 and 1995, $33.8 \%$ and $42.5 \%$ of employees, respectively, do not receive nominal wage increases. ${ }^{39}$ Nominal wages are rarely cut (only 8 out of 1957 times) when a worker is demoted. This partly results from rules in collective bargaining agreements which prescribe that the nominal wages of workers demoted to a lower job level can only be lowered after a period of advance notice which depends on the worker's age and tenure. But we observe that demoted workers are downgraded in the salary scales, which reduces their prospect of future wage growth.

\subsection{Wages and lateral mobility}

Wage ranges do not only differ for jobs at different hierarchical levels, but also for different jobs at the same hierarchical level. For example, catering staff, assembly workers and quality controllers are all in level 1, but the wage range spans scales 3-4 for catering jobs ( $97 \%$ of catering jobs have wages in that range), scales 4-8 for assembly workers, and scales 5-9 for quality controllers (95\% of quality controllers are in wage scales 5-9). This explains some of the within-level wage distribution depicted by Fig. 5. But it also implies that lateral job mobility is a source of wage growth when lateral transitions to jobs that span higher wage scales eventually lead to climbing the 
wage ladder. Such lateral job transitions associated with upward wage mobility exist and potentially mark "flatter" career paths.

An inspection of job titles gives rise to the conjecture that certain lateral job transitions characterize such "flatter" careers since titles of jobs further down such a flat career path often suggest differences in qualification requirements or responsibilities. Some apparent examples include movements from "Secretary of Department Chef" to "Secretary of the Head of the Department", from "Assembly Worker" to "Aircraft Mechanic", or from "Assembler Electrical Assembly A" to "Assembler Electrical Assembly B". In all three examples, the lateral transitions are to a job in which the median wage scale is higher and thus represent a career step for the individual worker. Such a career pattern is not rate: $45.0 \%$ of lateral movements are to jobs with a higher median wage scale. Only $19.1 \%$ are to jobs with a lower median wage scale.

Lateral job transitions are frequently associated with immediate wage changes: $21.9 \%$ of all lateral job transitions coincide with a wage change on the same date. Workers climb to a higher wage scale in $42.3 \%$ of these cases, while only $5.5 \%$ descend to a lower wage scale. On average, nominal hourly wages rise by $3.8 \%$ when a lateral transition coincides with a wage contract change. Wage growth is on average lower $(2.6 \%)$ for workers who have their wage contract adjusted some time after the lateral job change. Wage growth associated with a lateral job transition is higher in white-collar job levels than in blue-collar workers, but there are no significant differences in average wage growth of laterally transferred workers between periods of expansion and contraction.

\section{Careers}

Careers are a crucial characteristic of internal labor markets. According to the theory of internal labor markets careers help foster long-term employment relations and shield workers from external labor market conditions. This is desirable if firm-specific capital is important. We investigate whether firm-specific capital is important in our firm by assessing whether workers who are hired into a job level from outside differ in their characteristics from workers who are promoted to the same level from within. Then we describe job ladders that involve vertical job transitions and "flatter" career paths that consist of lateral job transitions in more detail. Especially for the latter type of career we ask whether jobs further down the career track are more attractive, both in terms of wages and the amount of shielding from external conditions.

\subsection{New hires versus incumbents}

To shed light on the question of whether specific-capital is important in our firm, we compare age and education levels of new hires to a given level and workers promoted from inside to the same level. Table 13 shows that new hires into levels $2-5$ are on average 4.5 to 7 years younger than incumbent workers who have been promoted to the same hierarchical level. Age differences are smaller in higher levels and almost negligible in levels 7 and 8 . 
Table 13. Age and tenure: New hires versus promoted incumbents

\begin{tabular}{|c|c|c|c|c|c|c|}
\hline \multirow[t]{3}{*}{ Level } & \multicolumn{4}{|l|}{ Age } & \multicolumn{2}{|l|}{ Tenure } \\
\hline & \multicolumn{2}{|l|}{ 1987-1991 } & \multicolumn{2}{|l|}{ 1991-1996 } & \multirow{2}{*}{$\begin{array}{l}\text { 1987-1991 } \\
\text { Promotee }\end{array}$} & \multirow[t]{2}{*}{ 1991-1996 } \\
\hline & Entree & Promotee & Entree & Promotee & & \\
\hline 1 & $24.5(6.8)$ & & $25.2(6.6)$ & & & \\
\hline 2 & $26.4(6.4)$ & $30.3(7.2)$ & $28.2(6.8)$ & $31.3(7.1)$ & $7.2(6.7)$ & $8.3(6.9)$ \\
\hline 3 & $27.8(6.0)$ & $35.0(8.2)$ & $28.4(7.4)$ & 34.9 (7.2) & $11.1(9.1)$ & $11.8(8.4)$ \\
\hline 4 & $27.5(4.8)$ & $35.4(8.6)$ & $26.7(4.9)$ & 34.9 (7.2) & $10.5(9.6)$ & $10.6(8.8)$ \\
\hline 5 & $30.6(6.7)$ & $34.4(7.2)$ & $28.1(4.4)$ & $34.7(6.8)$ & $8.5(8.0)$ & $8.3(7.4)$ \\
\hline 6 & $33.5(6.2)$ & $38.1(7.5)$ & $35.1(8.7)$ & $36.9(6.4)$ & $10.8(8.5)$ & $10.4(8.0)$ \\
\hline 7 & $39.3(6.6)$ & $39.1(6.1)$ & $39.3(6.1)$ & $39.8(6.1)$ & $11.2(6.8)$ & $11.8(7.6)$ \\
\hline 8 & $44.6(6.3)$ & $42.5(7.1)$ & $40.9(7.2)$ & $41.4(5.4)$ & $14.0(9.7)$ & $13.0(7.0)$ \\
\hline
\end{tabular}

Notes: The table compares entry ages and firm tenure of promoted incumbents and workers hired into the same level for the episodes of workforce expansion (1987-1991) and workforce contraction 1991-1996). Columns 2-5 show the mean ages of workers respective levels and provide standard deviations in parentheses below the respective means. Columns 6-7 report firm tenure of promoted workers. When judging the magnitude of the standard deviations, it should be taken into account that the age and tenure distributions are very skewed.

The pattern does not differ between periods. The two right-most columns show that promoted workers have on average been employed for 7 to 12 years in the firm. ${ }^{40}$ If firm-specific capital is important in the firm, promoted workers should have accumulated sizable levels of firm-specific capital during their elapsed tenure and new hires should compensate by either having more experience - which is unlikely given that they are substantially younger on average - or higher levels of education. Table 14 reveals that new hires indeed hold higher levels of general and vocational schooling degrees than promoted incumbent workers. So new hires seem to make up for lower levels of firmspecific capital with higher levels of general capital.

\subsection{Job ladders across hierarchical levels}

An important characteristic of our firm is the existence of different career paths, which sometimes span a number hierarchical levels. Vertical career paths commonly connect a number of jobs on different hierarchical levels within a particular field of activity. Yet, the set of hierarchical levels that is covered by a typical career differs across the various fields of activities, so that there are "pyramids within the hierarchical pyramid". For example, $97.8 \%$ of all workers in "Assembly" (F) are in the blue-collar ranks (levels 1-3). This might be contrasted with "Sales" where $85 \%$ of the employees are in management levels.

Two classes of career tracks can be identified in the white-collar ranks of "R\&D". The first class embraces a classical engineering career which involves concentration on technical aspects and specialization therein. Such a career path typically spans levels $4-6 .{ }^{41}$ Workers on an engineering career track typically start as "Staff Member of Engineering" on level 4, then they may become a "Specialist" or "Engineer" on level 5, and eventually they may be promoted to "Lead Engineer" or "Senior Specialist" (commonly in aircraft design) on level 6. The second class contains management careers in which 
Table 14. Education level: New hires versus promoted incumbents

\begin{tabular}{|c|c|c|c|c|c|c|c|c|c|c|}
\hline \multicolumn{11}{|c|}{ 1987-1991 } \\
\hline & \multirow[t]{2}{*}{ Job Level } & \multicolumn{9}{|c|}{ Education level } \\
\hline & & lo & lbo & mavo & llw & havo & mbo & vwo & hbo & uni \\
\hline \multirow[t]{2}{*}{2} & Promotees & 0.6 & 15.5 & 8.8 & 36.0 & 4.6 & 27.8 & 2.7 & 3.5 & 0.5 \\
\hline & Entrees & 0.0 & 4.1 & 8.8 & 5.0 & 9.1 & 42.0 & 6.3 & 20.8 & 3.8 \\
\hline \multirow[t]{2}{*}{3} & Promotees & 0.5 & 7.4 & 4.2 & 19.3 & 3.2 & 45.4 & 5.2 & 13.1 & 1.7 \\
\hline & Entrees & 0.0 & 0.6 & 5.4 & 2.4 & 4.2 & 16.7 & 6.5 & 44.0 & 20.2 \\
\hline \multirow[t]{2}{*}{4} & Promotees & 0.0 & 4.8 & 6.3 & 7.2 & 1.5 & 31.9 & 5.4 & 34.3 & 8.7 \\
\hline & Entrees & 0.0 & 0.2 & 1.2 & 0.4 & 3.3 & 2.7 & 14.7 & 39.0 & 38.4 \\
\hline \multirow[t]{2}{*}{5} & Promotees & 0.0 & 1.2 & 5.2 & 2.5 & 3.1 & 9.3 & 5.9 & 44.8 & 28.1 \\
\hline & Entrees & 0.0 & 0.0 & 0.7 & 0.0 & 1.3 & 1.3 & 17.0 & 19.0 & 60.8 \\
\hline \multirow[t]{2}{*}{6} & Promotees & 0.0 & 1.1 & 3.9 & 1.1 & 1.1 & 1.1 & 6.1 & 35.4 & 50.3 \\
\hline & Entrees & 0.0 & 0.0 & 0.0 & 0.0 & 3.2 & 3.2 & 22.6 & 22.6 & 48.4 \\
\hline \multirow[t]{2}{*}{7} & Promotees & 0.0 & 0.0 & 0.0 & 0.0 & 3.2 & 4.8 & 6.5 & 33.9 & 51.6 \\
\hline & Entrees & 0.0 & 0.0 & 4.5 & 0.0 & 0.0 & 0.0 & 13.6 & 31.8 & 50.0 \\
\hline \multirow[t]{2}{*}{8} & Promotees & 0.0 & 3.3 & 3.3 & 3.3 & 0.0 & 0.0 & 0.0 & 30.0 & 60.0 \\
\hline & Entrees & 0.0 & 0.0 & 0.0 & 0.0 & 0.0 & 0.0 & 0.0 & 50.0 & 50.0 \\
\hline \multicolumn{11}{|c|}{ 1991-1996 } \\
\hline & \multirow[t]{2}{*}{ Job Level } & \multicolumn{9}{|c|}{ Education level } \\
\hline & & lo & lbo & mavo & llw & havo & mbo & vwo & hbo & uni \\
\hline \multirow[t]{2}{*}{2} & Promotees & 0.4 & 10.4 & 10.9 & 33.0 & 4.9 & 35.4 & 2.1 & 2.7 & 0.2 \\
\hline & Entrees & 0.0 & 0.0 & 8.3 & 1.7 & 5.0 & 43.3 & 13.3 & 20.0 & 8.3 \\
\hline \multirow[t]{2}{*}{3} & Promotees & 0.7 & 5.8 & 5.1 & 20.7 & 5.1 & 49.5 & 0.4 & 10.5 & 2.2 \\
\hline & Entrees & 0.0 & 1.8 & 0.0 & 0.0 & 1.8 & 8.9 & 14.3 & 55.4 & 17.9 \\
\hline \multirow[t]{2}{*}{4} & Promotees & 0.0 & 5.0 & 3.1 & 10.0 & 4.6 & 36.4 & 2.3 & 28.7 & 10.0 \\
\hline & Entrees & 0.0 & 0.6 & 0.6 & 0.0 & 2.3 & 6.3 & 13.1 & 43.8 & 33.5 \\
\hline \multirow[t]{2}{*}{5} & Promotees & 0.0 & 1.3 & 2.5 & 2.3 & 1.5 & 12.4 & 7.9 & 44.4 & 27.7 \\
\hline & Entrees & 0.0 & 0.0 & 0.0 & 0.0 & 1.2 & 1.2 & 13.1 & 14.3 & 70.2 \\
\hline \multirow[t]{2}{*}{6} & Promotees & 0.0 & 0.9 & 3.6 & 1.4 & 2.7 & 6.3 & 10.8 & 34.2 & 40.1 \\
\hline & Entrees & 0.0 & 0.0 & 0.0 & 6.3 & 0.0 & 0.0 & 6.3 & 31.3 & 56.3 \\
\hline \multirow[t]{2}{*}{7} & Promotees & 0.0 & 1.4 & 2.9 & 0.0 & 0.0 & 2.9 & 7.1 & 34.3 & 51.4 \\
\hline & Entrees & 0.0 & 0.0 & 0.0 & 0.0 & 0.0 & 0.0 & 0.0 & 37.5 & 62.5 \\
\hline \multirow[t]{2}{*}{8} & Promotees & 0.0 & 0.0 & 3.0 & 0.0 & 3.0 & 9.1 & 9.1 & 21.2 & 54.5 \\
\hline & Entrees & 0.0 & 0.0 & 0.0 & 0.0 & 0.0 & 0.0 & 100.0 & 0.0 & 0.0 \\
\hline
\end{tabular}

Notes: The table compares highest obtained schooling degrees of promoted and workers hired into the same level for the episodes of workforce expansion (1987-1991, upper block) and workforce contraction 1991-1996, lower block). The cells show the pencentages of promotees or entrants with a given schooling degrees so that rows sum to 100 .

Education levels are defined in Table A.2 in the Appendix.

workers concentrate on supervision and handling of the day-to-day business. Positions in a management career track include "Design Division Leader" on level 4, "Project Leader" or "Chief of Engineering Group" on level 5, and "Head of Division" on level 6. It should be mentioned that career tracks comprising lower ranks also exist in $\mathrm{R} \& \mathrm{D}$. About $16 \%$ are employed in these ranks, working predominately as design engineers.

On a prevalent career path in "Sales \& Customer Relations" an employee starts on level 4 as an "Aircraft Analyst" or "Account Manager" and may eventually become an "Area Manager" or "Area Sales Manager" on level 8. 
This career track involves transitions to "Market Development Engineer" (level 5), "Account Development Manager" (level 6), and "Sales Manager" (level 7). Career tracks in lower levels also exist and are predominately followed by high-ranked blue-collar workers who transfer from production related activities. In particular, "Basic Instrument Experts" (level 2 in production) are promoted to "Instructors" (level 3) in "Sales \& Customer Relations" and may then proceed to become a "Technical Representative" on level 4. (We also observe inflow into this job from production workers on level 3.) Workers on this career track proceed to "Resident Technical Representative", but most careers that we observe end there. Only one person goes on to level 6 as "Customer Support Manager". Two persons make further careers by entering different jobs after having been a "Technical Representative". In general, we find that relatively fewer workers are hired from outside into positions further down a particular career path.

In addition, a substantial fraction of the inflow into career paths in "R\&D" and "Sales \& Customer Relations" has experience elsewhere in the firm. Only 35.2\% of workers who enter "Sales \& Customer Relations" from January 1987 until March 1991 are hired from outside. Those who enter from within the firm come predominately from "R\&D". Similarly, only $56.2 \%$ of new entrants into "R\&D" are new hires. Workers who transfer from other activities within the firm come predominately production activities $(73.6 \%)$. This finding underpins the importance of firm-specific knowledge, e.g., expertise and acquaintance with the firm's sophisticated product. The degree to which such firm-specific knowledge is important varies between different activities as one would expect. There is substantially less inflow from within relative to inflow from outside in administrative activities $(\mathrm{K}, \mathrm{H}, \mathrm{S})$. Between 1987 and 1991, when all non-production activities of the firm (Administrative activities (K, H, S), R\&D (C), and Sales \& Customer Relations (B)) grew at a similar rates (see Fig. 1), 64.5\% of all new entrants into administrative activities were recruited from outside.

An examination of job transitions across the five activities within production (Assembly (F), Support \& Supplies (G), Production Preparation (D), Planning \& Coordination (E), and Quality (M)) supports the conjecture that careers are important because some jobs build on expertise acquired in other jobs within the firm. A disproportionately large share of all workers who are hired into production activities during the expansion enters into "Assembly" (3062 of 4184). Only 309 workers enter "Assembly" from a job elsewhere in the firm, and only 140 of them enter into a job on level 1 , where more than $80 \%$ of workers in this activity are employed. During the same period, substantially more workers (818) leave "Assembly" for jobs in other activities within the firm - mostly jobs in one of the other 4 production related activities (578).

In contrast, 362 workers are hired into "Production Preparation", but 651 are transferred from within (267 of whom come from Assembly). "Quality" is the activity where hiring from outside (122) relative to transfers from within (327) is lowest. Most of the workers (208) who enter "Quality" worked in "Assembly" before and remain on the same job level (189). But they usually climb a wage scale upon the transition. Hence, these lateral transitions reflect careers within a job level. Other examples of such career monkey bars are discussed in the next section. It is noteworthy that $28.8 \%$ of all job changes - and $24.5 \%$ of lateral job changes - involve transitions 
to different fields of activity. Job transitions across different activities within the firm are more concentrated at the lower rungs of a career ladder and diminish further down a career track, implying that career decisions are for the large part taken early on, and career changes become rarer later in the employment relation.

\subsection{Monkey bars within hierarchical levels}

Careers within hierarchical levels are important. In fact, wriggling the monkey bars of a within-job-level-career is a more common phenomenon than climbing the career ladder by upward hierarchical job transitions. As already mentioned, examples include transitions from assembly workers to quality controllers, but also exist within more narrowly defined fields of activities. One particular, but typical, example is the transition from "Assembler Electrical Assembly A" to "Assembler Electrical Assembly B" which commonly does not result in an immediate advancement in wage scales, but does so eventually as the median wage scale is higher for the latter job. Roughly two thirds of lateral movements are transitions to jobs with a higher mean wage scale. ${ }^{42}$ More interesting, we observe 251 transitions from the first to the latter job, but only one worker is hired from outside to the latter job during the entire observation period. Jobs towards the higher end of within-job career tracks are less frequently filled from outside.

Within-job-level-careers are also common for secretaries. ${ }^{43}$ Lateral career movements frequently involve a transition from "Secretary of Section Chief" to "Secretary of Department Head". Again, we find that positions further down the career path, e.g., positions for "Secretary of Department Head" are more frequently filled by job transitions from within than by external hiring. However, entry from outside into positions further down the career path is more common for secretarial jobs than for jobs in, for example, "Production Preparation" or "Quality". An obvious explanation is the greater importance of firm-specific knowledge in the latter job activities.

Two generally important features of careers in our firm can be illustrated with the help of the 'secretary example': Firstly, lateral job transitions often represent an advancement on a "flatter" career track as they are to jobs that are better paid and less exposed to competition from outside. Secondly, lateral movements are sometimes stepping stones for upward transitions either within the vertical secretarial career path - secretaries can move upward to become "Secretary of Director" and further to become "Secretary of Executive Board Member" - or to other career paths within the firm - we also observe transitions to supervisory jobs (mostly in data processing), to higher-level administrative jobs, and eventually to lower level management jobs (mostly with tasks related to human resource management).

\section{Conclusion}

Our analysis confirms the existence of an internal labor market and the importance of lateral and vertical job mobility therein. Since wages are 
related to job levels, transitions are material for workers' wage growth. Although immediate gains upon promotions are small - often job transitions and wage changes do not even coincide - compared to the average difference in wages for adjacent job levels, promoted workers can look forward to a period of sustained wage growth as they move up in their new job level's wage distribution. The spread of these job-level wage distributions is substantial and wages in adjacent job levels overlap. In that sense, wages are not strictly tied to jobs as there remains considerable scope to reward workers based on individual characteristics.

Lateral job changes are a prevalent phenomenon involving more workers and more job changes than vertical job transitions. Wriggling the monkey bars in within-level careers is another valuable means for workers to secure wage growth. On the one hand, we find some evidence that lateral job transitions across different fields of activity improve future promotion prospects of blue-collar workers. On the other hand, we detected that lateral job mobility often represents a career step in itself. Lateral job mobility is on average associated with immediate wage increases. In addition, lateral transitions are frequently to jobs with higher median wage scales and thus provide scope for additional future wage growth within the new job. And finally, lateral job transitions are often to jobs that are less frequently filled by hiring from outside.

The staffing of positions from within is essential for the firm, especially in jobs that require firm-specific knowledge. Such organizational or firm-specific capital seems crucial in a number of jobs. Workers hired from outside seem to make up for the lack of firm-specific capital by having obtained higher completed schooling degrees than workers promoted from within. Even though entry occurs at all levels, entry rates are substantially lower in some career tracks for jobs further down the career path.

Changes in firm size in general and changes in relative entry and exit rates have a considerable impact on job transition rates. Promotion rates fall and demotion rates rise the more the net employment growth rates fall. The demotion rate for blue-collar workers increases by $40 \%$ during downsizing. We find that demotions are more frequent at our firm than in firms studied in related empirical work. This is partly explained by the fact that our firm experiences an episode of employment contraction during which demotion rates rise. But we also show that we would miss more than a quarter of all demotions if we only looked at year-end snapshots of the data as is commonly done in the empirical literature that studies personnel records of firms. A substantial number of workers leaves the firm shortly after a demotion, and many demotions occur shortly after workers had been promoted. We believe that these empirical findings should stimulate further theoretical work.

Finally, we find that the firm's job hierarchy is relatively stable throughout. The hierarchical job pyramid is neither augmented by job levels during expansion nor diminished during contraction. However, relative sizes of job levels change during downsizing when the firm becomes top-heavy. This is most likely the result of sizeable differences in adjustment costs for different workers, particularly when firm-specific capital is substantial in jobs further down a career path and future growth is expected as was the case at our firm. 


\section{Appendix: Definition of variables}

The following table summarizes the plant locations of the six different subsidiaries. The first column defines the categories that we distinguish in the paper:

Table A.1. Fokker subsidiaries and plant locations

\begin{tabular}{lll}
\hline $\begin{array}{l}\text { Location } \\
\text { name }\end{array}$ & Subsidiary & $\begin{array}{l}\text { Plant } \\
\text { locations }\end{array}$ \\
\hline FAC1 & Fokker Administration & $\begin{array}{l}\text { Amsterdam } \\
\text { Schipol }\end{array}$ \\
FAC1 & Fokker Aircraft 2 & Papendrecht/Dordrecht \\
FAC3 & Fokker Aircraft & Ypenburg \\
FSS & Fokker Aircraft & Leiden \\
ELMO & Fokker Space and Systems & Woensdrecht \\
FSP & Fokker ELMO & Hoogeveen \\
FAS & Fokker Special Products & Woensdrecht \\
\hline
\end{tabular}

Notes: Fokker Administration is located in the city of Amsterdam. In our data, it has the same location name (FAC1) as the main assembly plant at Schipol, which is due to historical reasons.

The following table defines the labels for schooling degrees used in the paper.

Table A.2. Schooling degrees

\begin{tabular}{ll}
\hline $\begin{array}{l}\text { Education } \\
\text { description }\end{array}$ & Type of education \\
\hline lo & \\
lbo & Basic education \\
mavo & Lower vocational degree \\
llw & Lower general schooling degree \\
havo & Apprenticeship \\
mbo & Intermediate general schooling degree \\
vwo & Intermediate vocational degree \\
hbo & Higher general schooling degree \\
uni & (qualifies for university enrollment) \\
\hline
\end{tabular}

Notes: The general schooling degrees, like basic education, lower, intermediate and higher general schooling degrees are prerequisites for pursuing a given vocational or general education in the Dutch educational system. Basic education is a prerequisite for any other degree. After having completed basic education, it is possible to either follow a lower vocational schooling course or to attend any of the school forms leading to a general schooling degree. Lower general education (mavo) makes one eligible to follow intermediate vocational training or complete an apprenticeship. An intermediate general schooling degree qualifies for higher vocational schooling, a higher general schooling degree (havo) qualifies for higher vocational schooling (hbo), while the highest level general schooling degree is a prerequisite for pursuing a college or university degree. In addition, it is possible to pursue the next higher schooling level after having obtained a given schooling degree; similarly it is possible to enter the next higher level of vocational schooling after having completed vocational schooling at the level just below, e.g., after having completed intermediate vocational schooling one is eligible to enter higher vocational schooling. 


\section{Endnotes}

${ }^{1}$ See Gibbons and Waldman (1999b) for a recent survey of this literature.

2 Dohmen (2003a) develops a model that generates a dependence relation between job mobility rates and employment rates.

3 The data were made available to us for academic purposes by the company's bankruptcy trustees. The report of the bankruptcy trustees is publicly available (see Deterink et al. 1997).

${ }^{4}$ Workers employed at this division leave our data files on that date.

5 Most analysts expected even in September 1995 that Fokker would survive when the majority shareholders, the Dutch government and Deutsche Aerospace AG (DASA), started negotiating a bailout plan. A comment in the Wall-Street Journal on September 4, 1995, describes the market sentiment: "Few, however, expect DASA, the aerospace arm of German industrial giant Daimler-Benz AG, will let Fokker go bust. The Dutch company [...] fills a key niche in a market segment expected to show strong growth in the next few years." (du Bois 1995)

${ }^{6}$ Some codes correspond to more than one name, which sometimes reflects typos, abbreviations in names, or a change from a Dutch to an English name. On the other hand, some job names are not unique to a single job code which often reflects the fact that codes have changed over time, while the job itself remained unchanged.

7 The largest 30 job codes comprise $35 \%$ of the workforce, and the largest 130 job codes encompass $50 \%$ of the workforce.

8 That we inferred the correct number of levels for white-collar employees from job transitions is confirmed by additional information on the firm's organizational structure of management which is provided by Deterink et al. (1997).

9 Wages for level 8 employees that exceed 200,000 guilders annually are also not recorded.

${ }^{10}$ It is noteworthy, however, that the firm apparently reorganized certain divisions during downsizing. For example, different engineering jobs are summarized in one job code in 1992.

11 The total number of hirings in the period of downsizing is less than a third of the inflow during expansion. Hiring rates into white-collar ranks fall by less than hiring rates into blue-collar employment (cf., lower part of Table 3).

12 This definition squares with additional information about the reason for wage contract changes. Wage contract changes that coincide with upward job transitions are frequently coded as a "promotion". Similarly, movements down the hierarchical ladder are often coded as a "demotion". Since only one reason for a wage-contract change is recorded, contract changes that involve job transitions but that occur on a date when the bulk of all wage contracts at the firm are changed are coded as "yearly increase" or "price compensation".

13 Summing up the length of all employment spells at the firm from January 1, 1987, until the date of bankruptcy yields a total of 102,147 employment years.

14 Clearly, this gives only an incomplete picture of total vertical mobility as it ignores offsetting vertical movements which occur when a worker is promoted and demoted within the period.

15 These percentages are calculated based on the absolute numbers of transitions underlying Tables 4 and 5 , but cannot be readily inferred from the tables 4 and 5 , as these average percentages for the fraction of all blue-collar workers and white-collar workers are weighted by the size of the levels.

16 Note that they have less time for vertical moves.

17 In Dohmen (2003a), corporate expansion triggers a higher promotion rate as hiring predominately takes place into the lowest hierarchical level while the firm fills additional positions on higher levels by promoting workers from within.

18 Campion et al. (1994) study these aspects of job rotation empirically.

19 Eriksson and Ortega (2001) find limited support for the employer learning hypothesis, but no favorable evidence for job rotation theories of employee learning and employee motivation in data from Danish private sector firms.

${ }^{20}$ For obvious reasons we only included observations of workers in this analysis who entered at least three years before the bankruptcy.

${ }^{21}$ Point estimates barely change when the level of education is added to the regression but all coefficient estimates then become insignificant.

${ }^{22}$ See Dohmen (2003b) for a detailed description of the formal salary system. 
23 The maximum wage in scale 12 can exceed the maximum wage in scale 13 because scale 12 absorbs all recently recruited white-collar employees who have not been assigned to a particular wage scale yet.

24 There is a high degree of coordination between unions and employer federations in the Netherlands (see Teulings and Hartog, 1998).

${ }^{25}$ Nominal contracts are characteristic for the Dutch labor market.

26 The nature of wage determination and the existence of fixed nominal wage contracts, which can be adjusted to aggregate conditions, helps solving hold-up problems in the way described by Teulings and Hartog (1998).

27 Averages are taken over wage contracts active on March 14 of each year.

28 Entry wages are much more variable in higher levels (levels 6 to 8), especially during downsizing.

${ }^{29}$ Differences pertain to the remarkable fact that the 5 th percentile wage in level 3 exceeds the 5 th percentile wage in level 4 in every year during the period of workforce expansion from 1987 until 1991, but not in later years. Since new hires typically start in the left tail of the withinlevel wage distribution and since level 4 serves as a port of entry for white-collar workers, the substantial number of new entrants in level 4 stretches out the left tail of the wage distribution in level 4 in these years. A similar pattern holds for level 1 wage distribution which is also more skewed to the right during years of substantial entry.

${ }^{30}$ Note that we do not observe wages for those workers in level 8 whose annual wages exceed a 200,000 Dutch guilders, so that the observed wage distribution is truncated.

${ }^{31}$ In fact, there is evidence in the data file description that a letter was sent to workers informing them about the fact that the highest wage in the job has been reached. Unfortunately, we lack the information when and to whom such a letter was sent.

${ }^{32}$ More than $80 \%$ have their wage contract changed within half a year after the upward transition.

33 Table 9 also discloses that the salary premium upon promotion is very similar during expansion and downsizing. In fact, Dohmen (2003b) shows that the salary system of the firm is not changed over time.

34 These regression results portray the pattern of serial correlation in individual wage growth well. Yet, we are aware that more sophisticated econometric techniques and estimators could improve the results along various dimensions, e.g., increase efficiency or account for learning effects (see Farber and Gibbons, 1996).

35 Empirical evidence for this kind of reciprocity is presented by Fehr et al. (1997), while Fehr and Schmidt (1999) provide a theoretical treatment.

36 Additionally, 1309 contracts have nominal wage cuts because of changes in working hours.

37 Wage drops are due to fewer shifts at ELMO during downsizing, i.e., result from reduced working hours.

${ }^{38}$ If we base our analysis on a yearly panel in which the cross sections are taken on March 14 in each year, we would observe only 134 nominal wage cuts.

39 Nominal wage freezes are more frequent for workers affected by collective bargaining agreements.

${ }^{40}$ It is not surprising that average tenure increases with job level in Table 13 as it reports average years of tenure since accession to the firm and not the average years spent in the job level from which the worker is promoted, which is obviously smaller for those who have experienced more than one promotion.

${ }^{41}$ Roughly $70 \%$ of the entire workforce in the activity field "R\&D" are employed in these levels. The number varies somewhat over time.

42 As for vertical job mobility, lateral career paths are no one-way route and "demotions" occur.

${ }^{43}$ Secretaries account for $2.2 \%$ to $2.5 \%$ of the workforce at all times, and $3.7 \%$ of all observed workers have been a secretary at some point in time.

\section{References}

Ariga K, Ohkusa Y, Brunello G (1999) Fast Track: Is it in the Genes? The Promotion Policy of a Large Japanese Firm. Journal of Economic Behavior and Organization 38(4): 385-402 
Baker G, Gibbs M, Holmstrom B (1994a) The Internal Economics of the Firm: Evidence from Personnel Data. Quarterly Journal of Economics 109(4): 881-919

Baker G, Gibbs M, Holmstrom B (1994b) The Wage Policy of a Firm. Quarterly Journal of Economics 109(4): 921-955

Bewley TF (1999) Why wages don't fall during a recesssion. Harvard University Press, Cambridge, MA

Blinder AS, Choi DH (1990) A Shred of Evidence on Theories of Wage Stickiness. Quarterly Journal of Economics 105(4): 1003-1015

Calvo G, Wellisz S (1979) Hierarchy, Ability, and Income Distribution. Journal of Political Economy 87(5): 991-1010

Campion, MA, Cheraskin L, Stevens, MJ (1994) Career-Related Antecedents and Outcomes of Job Rotation. Academy of Management Journal 37(6): 1518-1542

Deterink A, Knüppe B, Leuftink A, Schimmelpenninck R (1997) Bankruptcy Trustees' Investigation of the Causes of the Bankruptcy of N.V Koninklijke Nederlandse Vliegtuigfabriek Fokker, Fokker Aircraft B.V, Fokker Admininstration B.V. Kluwer, Deventer

Doeringer PB, Piore MJ (1971) Internal Labor Markets and Manpower Analysis. Heath Lexington Books, Lexington, MA

Dohmen TJ (2003a) A Theory of Careers in Hierarchical Internal Labor Markets. Manuscript prepared for the 2003 Annual Conference of the Royal Economic Society at the University of Warwick

Dohmen TJ (2003b) Performance, Seniority, and Wages: Formal Salary Systems and Individual Earnings Profiles. 1ZA DP 935, 1ZA Bonn

Dohmen TJ, Pfann GA (2004) Worker Separations in a Nonstationary Corporate Environment. European Economic Review 48(3): 645-663

du Bois M (1995) Aircraft Maker Fokker Faces a Bumpy Ride As Netherlands, DASA Begin Bailout Talks. Wall Street Journal Europe

Eriksson T, Ortega J (2001) The Adoption of Job Rotation: Testing the Theories. Paper presented at Universidad Publica de Navarra (January 25, 2002)

Farber HS, Gibbons R (1996) Learning and Wage Dynamics. Quarterly Journal of Economics 111(4): 1007-1047

Fehr E, Gächter S, Kirchsteiger G (1997) Reciprocity as a Contract Enforcement Device. Econometrica 65(4): 833-860

Fehr E, Schmidt KM (1999) A Theory of Fairness, Competition and Cooperation. Quarterly Journal of Economics 114(3): 817-868

Gibbons R (1997) Incentives and Careers in Organizations. In: Kreps D Wallis K (eds) Advances in Economics and Econometrics: Theory and Applications (II). Cambridge University Press, Cambridge

Gibbons R, Waldman M (1999a) A Theory of Wage and Promotion Dynamics Inside Firms. Quarterly Journal of Economics 114(4): 1321-1358

Gibbons R, Waldman M (1999b) Careers in Organizations: Theory and Evidence. In: Ashenfelter OC Card D (eds) Handbook of Labor Economics (3B). Elsevier Science, Amsterdam and New York, pp 2373-2437

Gibbons R, Waldman M (2003) Enriching a Theory of Wage and Promotion Dynamics inside Firms. NBER Working Paper 9849, NBER, Cambridge, MA

Gibbs M, Hendricks W (2001) Are Formal Salary Systems a Veil? Working Paper, University of Chicago

Lazear EP (1979) Why is There Mandatory Retirement? Journal of Political Economy 87(6): 1261-1284

Lazear EP (1992) The Job as a Concept. In: Bruns W (ed) Performance Evaluation and Incentives. Harvard Business School Press, Boston pp 183-215

Lazear EP, Rosen S (1981) Rank-Order Tournaments as Optimum Labor Contracts. Journal of Political Economy 89(5): 841-864

Lima F (2000) Internal Labor Markets: A Case Study from an Institutional Survey. Working Paper, Universidada Nova Lisboa

MacLeod W, Malcomson J (1993) Investment, Holdups, and the Form of Market Contracts. American Economic Review 83(4): 811-837

Medoff JL, Abraham KG (1980) Experience, Performance, and Earnings. Quarterly Journal of Economics 95(4): 703-736 
Milgrom P, Roberts J (1988) An Economic Approach to Influence Activities in Organizations. American Journal of Sociology 94 (Supplement): S154-S179

Oi WY (1962) Labor as a Quasi-Fixed Factor. Journal of Political Economy 70(6): 538-555

Ortega J (2001) Job Rotation as a Learning Mechanism. Management Science 47(10): 1361-1370

Osterman P (1979) Sex Discrimination in Professional Employment: A Case Study. Industrial and Labor Relations Review 32(4): 451-464

Prendergast C (1993) A Theory of "Yes Men". American Economic Review 83(4): 757-770

Prendergast C, Topel R (1996) Favoritism in Organizations. Journal of Political Economy 104(5): 958-978

Prescott EC, Visscher M (1980) Organization Capital. Journal of Political Economy 88(3): 446-461

Rosen S (1982) Authority, Control, and the Distribution of Earnings. Bell Journal of Economics 13(2): 311-323

Rosen S (1986) Prizes and Incentives in Elimination Tournaments. American Economic Review 76(4): 701-715

Rosenbaum JE (1984) Career Mobility in a Corporate Hierarchy. Academic Press, London

Seltzer A, Merrett D (2000) Personnel Policies at the Union Bank of Australia: Evidence form the 1888-1900 Entry Cohorts. Journal of Labor Economics 18(4): 573-613

Teulings CN, Hartog J (1998) Corporatism or Competition? Cambridge University Press, Cambridge

Treble J, Barmby T, Bridges S, van Gameren E (2001) The Internal Economics of The Firm: Further Evidence From Personnel Data. Labour Economics 8(5): 531-552

Waldman M (1984) Job Assignments, Signalling, and Efficiency. Rand Journal of Economics 15(2): $255-267$ 
Copyright of Journal of Population Economics is the property of Springer Verlag New York, Inc. and its content may not be copied or emailed to multiple sites or posted to a listserv without the copyright holder's express written permission. However, users may print, download, or email articles for individual use. 
Copyright of Journal of Population Economics is the property of Springer Verlag New York, Inc. and its content may not be copied or emailed to multiple sites or posted to a listserv without the copyright holder's express written permission. However, users may print, download, or email articles for individual use. 